\title{
A CAVALCADE OF FIELD BOTANISTS IN OKLAHOMA - CONTRIBUTORS TO OUR KNOWLEDGE OF THE FLORA OF OKLAHOMA
}

\author{
Ronald J. Tyrl \\ Paula A. Shryock \\ Dept. of Botany \\ Oklahoma State University
}

As members of the Oklahoma Native Plant Society (ONPS) well know, Oklahoma has a tremendous diversity of vascular plants-174 families, 854 genera, and approximately 2,600 species-that reflects the ecogeographic diversity present within the state's borders (Tyrl et al. 2008). Our knowledge of this flora is the result of contributions by numerous individuals for more than 450 years. Some simply recorded their observations of the state's flora as they passed through; whereas, others made systematic surveys and documented their work by actually collecting plants for voucher specimens to be deposited in herbaria.

These individuals and the contributions that they have made to our knowledge of the plants and vegetation of Oklahoma are the subject of this essay. Its title and concept are rooted in a presidential address given by H.I. Featherly in 1942 to the Oklahoma Academy of Science and a master's thesis by Wanona Henson, one of his graduate students (Henson 1941; Featherly 1943). We have unabashedly adopted their approach and excerpted some of their thoughts about the state's first field botanists in our synopses. As they did, we present our individuals more or less chronologically. Each synopsis comprises a brief biographical sketch and the botanical contribution(s) they made. When specific plants are cited, currently accepted scientific names are used unless otherwise noted. Common names are taken from Taylor and Taylor (1994), Tyrl and coworkers (2008), Folley (2011), and USDA, NRCS (2013).
Francisco Vásquez de Coronado-Our cavalcade of field botanists begins with Coronado, whose 1540-1542 expedition in search of the fabled city of gold is the first documented trek by Europeans across the plains and prairies later to become Oklahoma. Coronado was not a botanist nor was there a botanist with his group. He did not make a list of the plants that he saw on his expedition, but he did describe the general appearance of the country. Describing his journey northward through Oklahoma, he wrote in his report to Emperor Charles V of Spain: "...there is not any kind of wood in all these plains, away from the gullies and rivers which are very few." (Dale and Rader 1930).

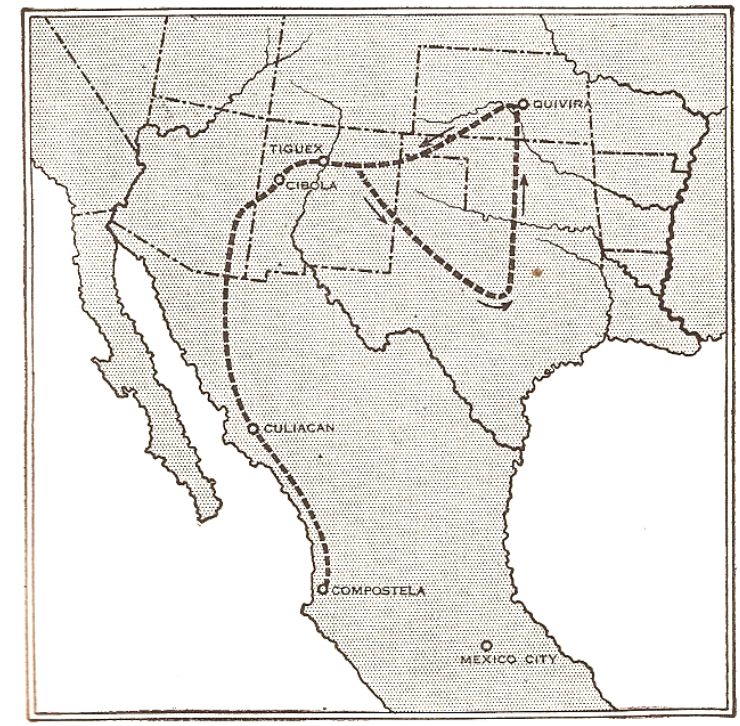

Figure 1 Putative route of Coronado's travel in Oklahoma (Buchanan and Dale 1939).

Ronald J. Tyrl and Paula A. Shryock https://doi.org/10.22488/okstate.17.100099 
It is thought that his route northward was along the 98th Meridian. He possibly passed between the Wichita and Arbuckle Mountains, through the El Reno area, and on north to the Arkansas River (Buchanan and Dale 1939; Figure 1 above).

Hodge (1907) suggested that his route was perhaps closer to the 100th Meridian which marks the western boundary of the body of Oklahoma (Figure 2). His return from Quivira in modern-day Kansas, a city that he thought was going to be a source of wealth but was actually a village of semi-nomadic Plains Indians, ran along the course of what was later to be known as the Cimarron Cut-Off of the Santa Fe Trail.

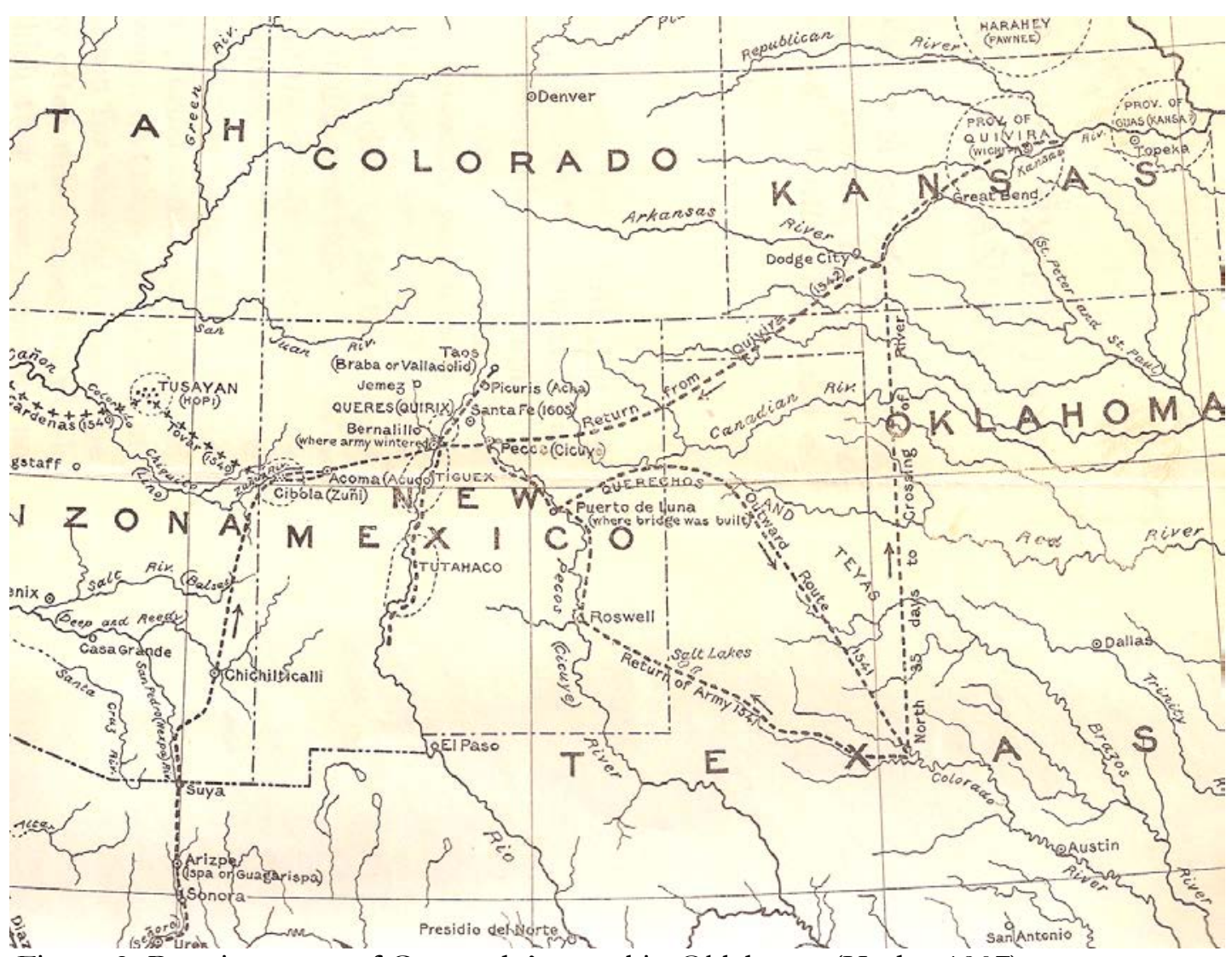

Figure 2 Putative route of Coronado's travel in Oklahoma (Hodge 1907).

Juan de Oñate-In 1601, Juan de Oñate, governor of New Mexico, led another expedition into the North, also in search of Quivira. The map he drew of his route shows that he also crossed Oklahoma (Bolton 1916). Entering the state from the west at about $36^{\circ} \mathrm{N}$ in Ellis County, he followed the Canadian River (which he named the Magdalena), angled to the northeast, and exited at about $98^{\circ} \mathrm{W}$ near Manchester in Grant County. Like Coronado, de Oñate was not a botanist and did not have one with him. However, in his report of the journey (1601), he described the surrounding landscapesand dunes, extensive level plains, deep ravines, and broken hills. These are now known as the geomorphic provinces: Western Sand Dune Belts, Central Redbed Plains, Western Sandstone Hills, and Cimarron Gypsum Hills (Curtis and Ham 1972). He also cited the edible plants his group encountered. 
For example, he wrote:

And the fruits gave no less pleasure, particularly the plums, of a hundred thousand different kinds, as mellow and good as those which grow in the choicest orchards of our land. They are so good that although eaten by thousands they never injured anybody. The trees were small, but their fruit was more plentiful than their leaves, and they were so abundant that in more than one hundred and fifty leagues, hardly a day passed without seeing groves of them, and also grapevines such that although they hid the view in many places they produced sweet and delicious grapes.

De Oñate undoubtedly was describing thickets of sand plums (Prunus angustifolia). After crossing the Cimarron River, he wrote:

...for many leagues... the fields there were covered with flowers of a thousand different kinds, so thick that they choked the pasture. The cattle of this territory must eat the flowers far better than ours are wont to, because wherever they were there were multitudes of cattle.

James Biddle Wilkinson-The person credited with the first official description of the ecogeography of Oklahoma was Lieutenant J.B. Wilkinson, a member of the Zebulon Pike Expedition of 1806 and 1807 to explore the poorly defined south and west boundaries of the Louisiana Purchase where it abutted the region claimed by Spain (Jackson 1966). Pike left Fort Bellefontaine near St. Louis; followed the Missouri, Osage, and Republican Rivers; and eventually traveled overland to reach the Arkansas River near the present day town of Great Bend, Kansas. On October 28th, 1806, Pike divided his group into two parties and assigned Lt. Wilkinson and five men the task of following the Arkansas River downstream to its junction with the Mississippi River. On December 31, the party passed the mouth of the Poteau River at the eastern edge of Oklahoma (Buchanan and Dale 1939). Wilkinson made extensive notes on the geographic and topographic features of the country through which he passed. He also made brief notes on the vegetation and some of the plants he encountered, but he did not make a formal list of the plants seen. His report, included in Pike's (1810) report of the expedition to the government, was the first description of a part of Oklahoma by an American (Dale and Rader 1930).

George C. Sibley-A brief acknowledgement of George Sibley's observations of one of Oklahoma's most interesting ecogeographic sites is appropriate. Appointed in 1808 as the head trader at the Indian Factory at Fort Osage, Missouri, he led a party of interpreters and Osage scouts on a two-month exploration in May 1811, intended to improve relations between the Kansa and the Pawnee Indians and to examine the hunting grounds of the Osage Indians (Tyson 2009). During his visit with the Osage at villages along the Arkansas River near the mouth of the Verdigris River, Sibley traveled to the Great Salt Plains. Calling the area the "Grand Saline," he described the plains by writing:

This beautiful white dazzling surface (bordered by a fringe of verdant green) bas the effect of looming, as the sailors call it, producing to the unpracticed eye, much delusion.

As de Oñate had done, he feasted on sand plums and recorded in his diary:

...barren sand bills (not red sand) on the sides of which are here and there a few dwarf plum bushes not over thirty inches high from which we gathered abundance of very large delicious red plums.

(Sibley 1927)

Sibley also noted in his diary that, according to the Osage Indians accompanying him, he was the first white man to visit the area. He also visited an area he called the "Rock Saline" that is probably the salt springs near the 
Blaine Escarpment on the upper Cimarron River (Tyson 2009).

Thomas Nuttall-An Englishman from Yorkshire, England, Thomas Nuttall (Figure 3) is generally acknowledged to be the first botanist to visit what is now Oklahoma (Featherly 1943). Although he had no formal education, he published papers and books in botany, geology, and zoology. He was among the first individuals to champion the use of a natural classification for plants in the United States, and he authored a botany textbook (Lawrence 1951; Graustein 1967). His two volume A Manual of the Ornithology of the United States and of Canada, published in 1832 and 1834, was the first systematic treatment of North American birds.

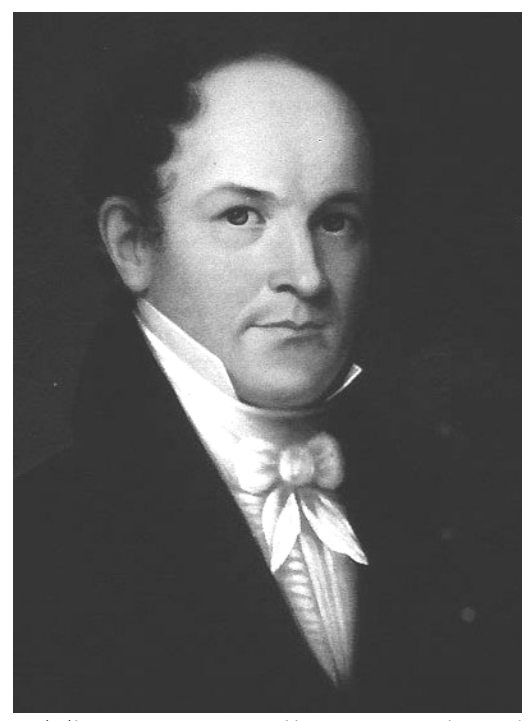

Figure 3 Thomas Nuttall. Harvard University Portrait Collection.

Nuttall's principal biographer Jeannette E. Graustein (1967) gives a most comprehensive and informative account of his early life and career which forms the basis for the following comments. At 14 years of age, Nuttall began an apprenticeship as a printer for his uncle in Liverpool. He apparently spent his Sundays and spare time reading books on the natural history, botany, and geology of The Pennines (an irregular chain of hills in Northeast England) and botanizing with surgeon and botanist John Windsor. As an apprentice printer, Nuttall was likely involved in the printing of the Liverpool museum's catalogue of plant and animal specimens, arranged according to the Linnean system of classification.

When Nuttall's seven-year apprenticeship ended in 1807, he refused to join his uncle's printing company and decided to pursue a career in natural history. Why he chose to travel to North America is unknown, although Graustein suggested that he may have been influenced by his reading of Francois André Michaux's 1805 Travels to the Westward of the Allegheny Mountains in the States of The Ohio, Kentucky and Tennessee in the Year 1802 and/or Alexander von Humboldt and Aime Bonpland's 1805 Essai sur la Géographie des Plantes. Regardless of the reason, his career as a naturalist began in 1808 when he immigrated to Philadelphia. There, he met the famous American botanist Benjamin Smith Barton who started him on his career as an explorer and botanist. He began collecting plants for Barton and for Philadelphia University; his first field work was in the salt marshes of Delaware and Chesapeake Bay in 1809 (Thwaites 1905; Reveal 1998). Barton asked him to botanize in the Great Lakes Region in the summer of 1810 . While doing so, he joined an expedition of John Jacob Astor's American Fur Company and in 1811 began making his way up the Missouri River eventually reaching Fort Mandan in present day North Dakota. Although Lewis and Clark had traveled this way previously, many of their plant specimens had been lost. Thus, those collected by Nuttall on this trip were species new to science.

On October 2, 1818, Nuttall left Philadelphia to explore "the Southwest" modern day Arkansas and Oklahoma. Four fellow members of the American Philosophical Society, to which Nuttall had been elected in 1817, made donations to defray the expenses of the trip (Lottinville 1980). He traveled overland to Pittsburgh, down the Ohio and Mississippi Rivers to the 
Arkansas River, and then up to Fort Smith, which he reached on April 24, 1819. He began collecting in the spring meadows, and in the course of a few weeks he collected about a hundred new species, including the familiar Nemastylis geminflora (celestial lily), Callirhoe digitata (finger poppy mallow), Collinsia violacea (violet blue-eyed Mary), and Verbena bipinnatifida (prairie verbena) (Nuttall 1821; Graustein 1967). His collecting companion was Dr. Thomas Russell, who was the surgeon at Fort Smith. Unfortunately he died of a fever four months after Nuttall met him. Monarda russeliana Nutt. (Russell's beebalm) honors him.
In mid-May, Nuttall accompanied a Major Bradford, six soldiers, and two Cherokees south to the Red River. His route, experiences, and botanical observations are described in detail in his journal (1821) and by Geiser (1956). Bradford was instructed to order any white settlers he found off land granted to the Osage Indians (Graustein 1967). Their route took them along the Poteau River, near Cavaniol (Cavanal) and Sugar-Loaf Mountains, and across Winding Stair Mountain in the Ouachita Mountainsor as they were called then, the Mazern Mountains - to the Kiamichi and Red Rivers (Figure 4).

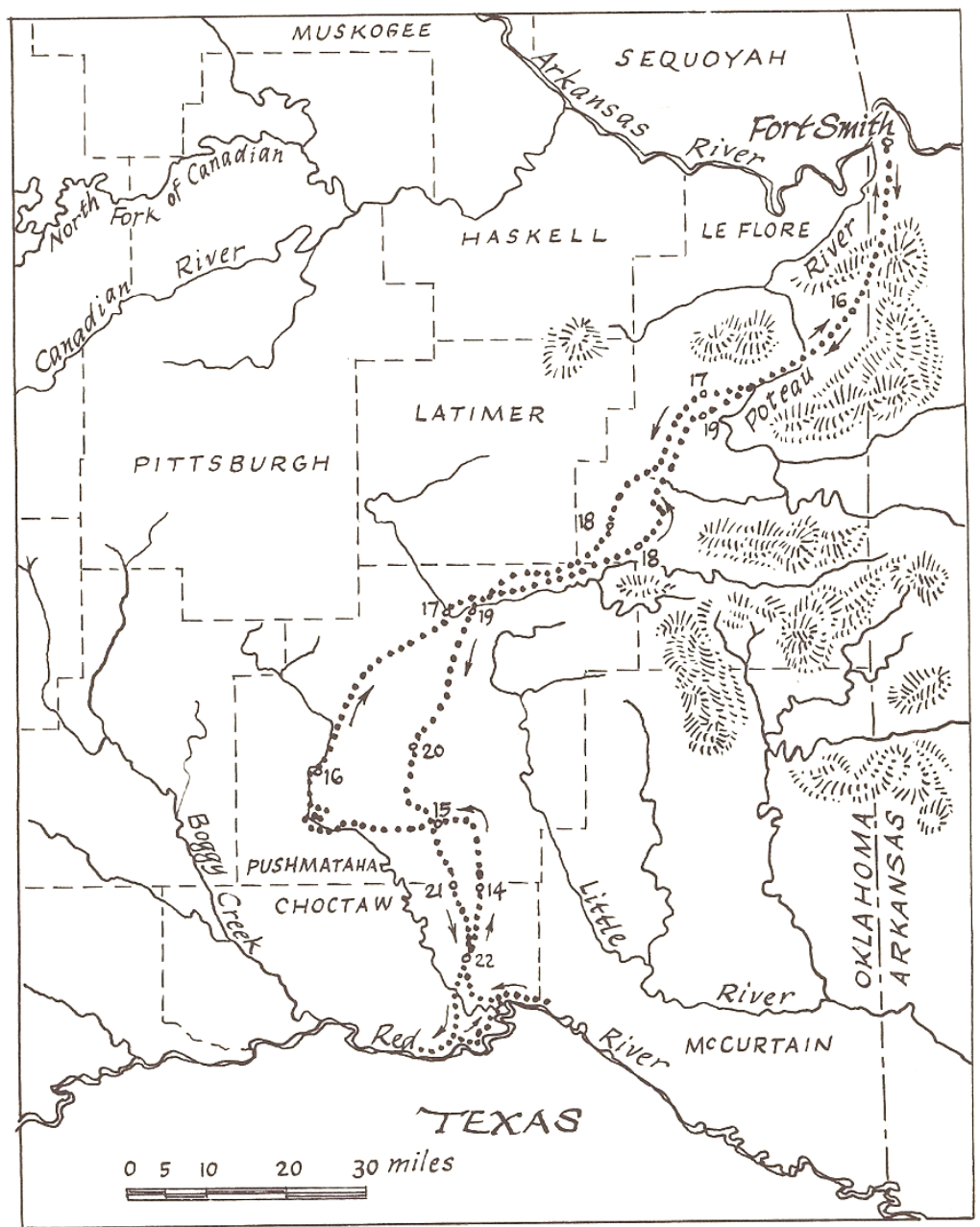

Figure 4 Route of Nuttall's travel to the Kiamichi and Red Rivers (Lottinville 1980). Courtesy of the University of Oklahoma Press. 
As always, Nuttall diligently and poetically made observations of the landscape and on May 23 wrote:

The change in the soil in the great Prairie of the Red river now appeared obvious. It was here that I saw the first calcareous rock charged with shells, \&c. since my departure from the banks of the Obio. Nothing could at this season exceed the beauty of these plains, enameled with such an uncommon variety of flowers of vivid tints possessing all the brilliancy of tropical productions.

Bradford's party remained in the vicinity of the Red River for three days before they started back to Fort Smith. Nuttall, however, lingered behind to collect several new plants, got lost, and never again rejoined Bradford.

He took a wrong turn in the trail, went miles in the wrong direction, spent the night at a settler's house (who had just been ordered by Bradford to leave his home), lost his horse who wandered away in the night, stayed with another settler family for three weeks, and on June 14 started back to Fort Smith in the company of three hunters from the Red River settlements. Apparently Nuttall wasn't too disconcerted at being left behind, as he collected new species for 19 days. On June 4 he wrote in his journal:

The singular appearance of these vast meadows, now so profusely decorated with flowers, as seen from a distance, can scarcely be described. Several large circumscribed tracts were perfectly gilded with millions of the flowers of Rudbeckia amplexicaulis bordered by other irregular snow white fields of a new species of Coriandrum (now Biflora americana, prairie bishop).

On June 6, he wrote: "Today I went five or six miles to collect specimens of the Centaurea (now Plectocephalus americanus, basket-flower), which as being the only species of this numerous genus indigenous to America, had excited my curiosity." In terms of species new to science, familiar showy representatives discovered by Nuttall include Penstemon cobaea (large prairie beardtongue), Platanthera leucophaea (eastern prairie fringed orchid), Sabatia campestris (prairie rose gentian), Oenothera speciosa (showy evening primrose), Marshallia caespitosa (Barbara's buttons), and Rudbeckia maxima (giant coneflower).

Nuttall stayed at Fort Smith until July 6. He hitched a ride on a boat with traders going up the Arkansas River to a trading post which had been established at the mouth of the Verdigris River (Figure 5). On July 14, he reached the Verdigris and the Bougie (Bogy) Trading Post. Nuttall was a careful observer of the country through which he was passing and described it in detail. Much of our understanding of what the vegetation was like before European settlement can be attributed to his descriptions. For example, he wrote on July 13:

The variety of trees which commonly form the North American forest, bere begin very sensibly to diminish. We now scarcely see any other than the smooth barked cottonwood, the elm, the box-elder (Acer negundo), the curled maple (Acer dasycarpon), and ash; all of them reduced in stature. From bence the forest begins to disappear before the prevailing plain."

On July 17, he traveled by canoe about 50 miles up the Grand River with two companions to visit a salt works (springs) and reached it two days later. While his traveling companions continued their journey up the river, Nuttall, using a compass to maintain his heading, walked alone overland across the prairie to the trading post. On July 20 he wrote: "Twenty miles of this route was without any path, and through grass three feet deep, often entangled with brambles, and particularly with the tenacious 'saw-brier' (Schrankia horridula)."' Schrankia horridula is now Mimosa quadrivalvis, catclaw sensitivebriar. He spent one night in the open prairie without fire, food, or water.

An interesting aside is that Nuttall, the night before setting out on his walk, dosed himself with "... about a pint of a strong and bitter decoction, of the Eupatorium cuneifolium..." in

Ronald J. Tyrl and Paula A. Shryock 


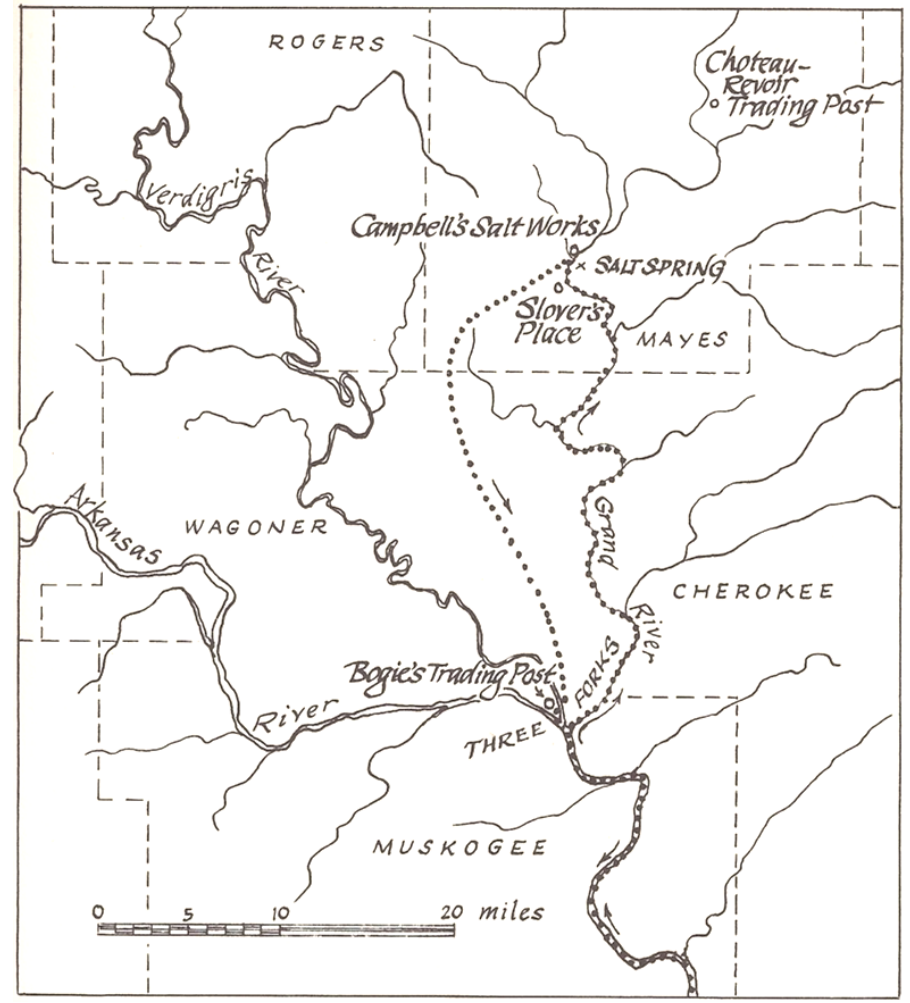

Figure 5 (left) Route of Nuttall's travel to the three rivers junction (Lottinville 1980). Courtesy of the University of Oklahoma Press.

Figure 6 (below) Route of Nuttall's travel to central Oklahoma (Lottinville 1980). Courtesy of the University of Oklahoma Press.

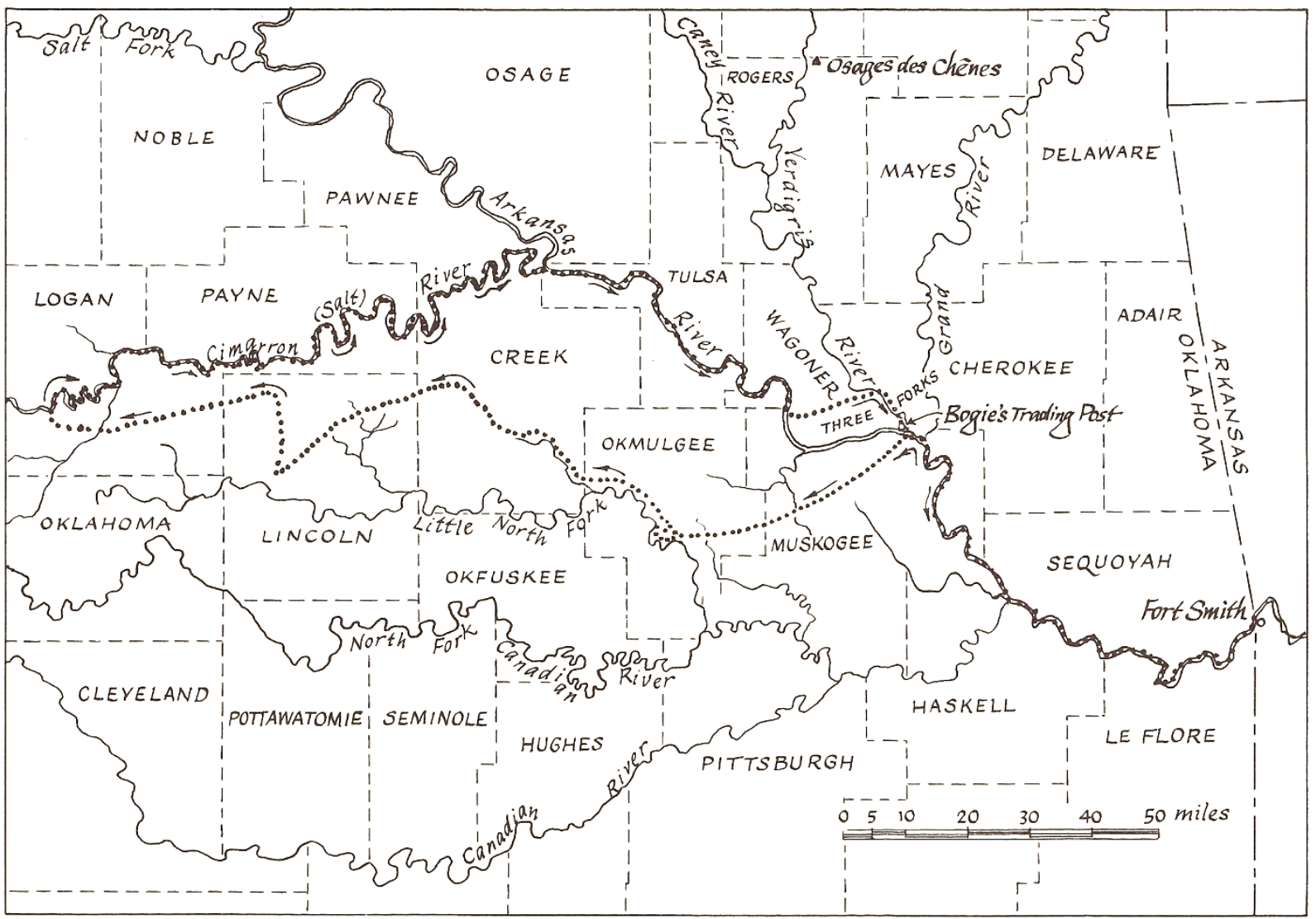

Ronald J. Tyrl and Paula A. Shryock 
response to a "...slight attack of intermittent fever..." Because E. cuneifolium does not occur in Oklahoma, it is likely that his decoction comprised one of the other species of the genus present in the area (Lottinville 1980; Lawson 2004).

A cherished goal of Nuttall was to botanize in the Rocky Mountains. To avoid the circuitous course of the Arkansas River mapped by Wilkinson and Pike, he decided to follow the Cimarron River westward and return via the Red River (Figure 6; Graustein 1967; Lottinville 1980). On August 11, he left the Bougie Trading Post at the mouth of the Verdigris River accompanied by an experienced hunter-trapper named Lee who had previously traveled west to the Rockies (Lottinville 1980). On horseback, they traveled overland from the Arkansas River to the Little North Fork of the Canadian River (now called the Deep Fork River), followed it for a while, and again traveled overland to the Cimarron River and westward. As they traveled, Nuttall recorded his observations of the changing landscape and botanized.

The trip was quite an ordeal for Nuttall because three days into the journey (August 14) on the banks of the Deep Fork, he suffered a relapse of the remittent fever he had contracted while at the trading post at the mouth of the Verdigris River. He became desperately ill, often was delirious, ran high fevers, lost his appetite, and became increasingly weak. Lee thought he was going to die and suggested turning back. Nuttall resisted returning and talked Lee into going farther west. To make matters worse, the area was in the midst of a heat wave and drought and thus the scarce water in the streams was "... always stagnant and often putrid." In addition, the two men and their horses were plagued by blowflies and their maggots. They finally reached the Cimarron River on September 3 and followed it westward until September 8 when the ailing Nuttall gave in and agreed to give up his quest to reach the Rocky Mountains. He and Lee started downstream in a canoe built by Lee. They likely only traveled as far west as Guthrie in Logan County (Lottinville 1980). Lottinville's conclusion is based on Nuttall's journal entry on September 3: "A few days journey to the west, $M r$. Lee informs me, that there are extensive tracts of moving sand hills, accompanied by a degree of sterility little short of the African deserts." Lee is obviously referring to the Western Sand Dune Belt geomorphic province with its characteristic Quaternary sands deposited on the north and east sides of the Cimarron River (Curtis and Ham 1972).

Even while sick and struggling to return to the trading post, Nuttall was recording the discovery of new species, such as Happlopappus ciliata (wax goldenweed, now Grindelia ciliate, Eriogonum annuum (annual buckwheat, and Tidestromia lanuginosa (woolly tidestromia). On September 15, Nuttall finally reached the Bougie Trading Post. "...In a very feeble state, again visited by fever, and a kind of horrific delirium...", he was nursed by Bougie for a week and then traveled down the Arkansas River to Fort Smith. He continued to be sick and weak, and in late April he returned to Philadelphia (Graustein 1967).

Upon his return, his patrons urged him to write an account of his travels based on his daily journal entries. He reluctantly agreed to do so and in November of 1821 published his A Journal of Travels into the Arkansa Territory, During the Year 1819 with Occasional Observations on the Manners of the Aborigines. He dedicated the book to the four individuals who financed the trip. In 1834, he read a paper before the American Philosophical Society in which he listed 550 species from Arkansas and Oklahoma. The list was subsequently published in 1837 (Nuttall 1837). Based on the number of species in the families Asteraceae (sunflowers) and Fabaceae (legumes) described by Nuttall, Geiser (1956) estimated that about $9.6 \%$ of Oklahoma's plant species were given names by him. Indeed, 31 of the state's 850 genera and 211 of its 2,465 species were described by him (Tyrl et al. 2010). In addition, 13 Oklahoma species have the specific epithet nuttallii or 
nuttalliana honoring him, as does the genus Nuttallanthus.

The 1837 publication of Nuttall's species list is considered to be the first documented collection of the state's flora (Johnson and Milby 1989). His contributions to our knowledge of the flora of Oklahoma and North America is perhaps best summarized by the famous taxonomist Asa Gray who wrote (Ewan 1969) in 1844:

...no botanist has visited so large a portion of the United States, or made such an amount of observations in field and forest. Probably few naturalists have ever excelled him in aptitude for such observations, in quickness of eye, tact, in discrimination and tenacity of memory.

Edwin James-In 1820, Major Stephen H. Long's expedition to the Rocky Mountains passed east through Oklahoma along the Canadian River (Goodman and Lawson 1995). Commissioned by President James Monroe in 1818, the purpose of the expedition was to find the sources of the Platte, Arkansas, and Red Rivers in the Rocky Mountains and to gather scientific information. The party included a zoologist, a naturalist, and a botanist. A replacement for a Dr. William Baldwin who died in Missouri in the initial stages of the trip, Edwin James (Figure 7) was the expedition's botanist, geologist, and surgeon (Ewan 1950). Twentythree years old, he kept a journal of his observations that was the basis for his three volume Account of an Expedition from Pittsburg to the Rocky Mountains... in the Years 1819, 1820 Under the Command of Major Stephen H. Long..., published in 1823 (James 1823).

As Benson (1968) and Goodman and Lawson (1995) have noted, the significance of James's work is that he returned with hundreds of plant specimens from areasNebraska, Colorado, New Mexico, Texas, and Oklahoma - that hadn't been visited before by botanists. His collections encompassed the central grasslands, the coniferous woodlands and forests of the Rocky Mountains, and for

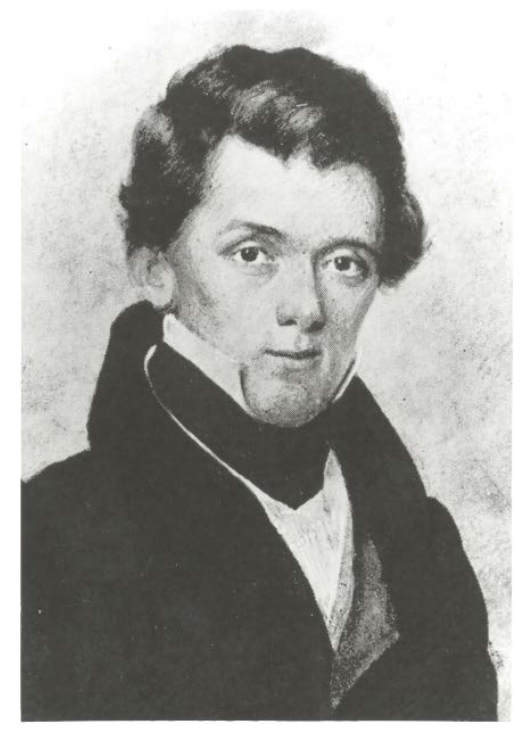

Figure 7 Edwin James. Photo courtesy of Hunt Institute for Botanical Documentation, Carnegie Mellon University, Pittsburgh, Pennsylvania.

the very first time the alpine zones of the Colorado Rockies. They also stress that his accomplishments are quite remarkable considering that he was only in the field for one hundred days and was transporting his specimens via packhorses. Well over 100 of the plants he collected were new to science. He had quite a sharp eye for different species. When he reported the first occurrence of a plant in his journal, the location often later proved to be the eastern or western limit of that species' distribution. In addition to collecting and listing the species he encountered, James entered almost daily observations of the vegetation and geography of the area through which the expedition passed, thus giving us a description of what the landscape was like before European settlers and accompanying alien plants began to change it.

James published a partial plant list in 1825, but it was the famous taxonomist John Torrey who published most of James's discoveries. In three lengthy publications, Torrey described the new species and honored James by naming several for him (Torrey 1824a, 1824b, 1827). Illustrative of 
this honor are two Oklahoma species:

Eriogonum jamesii (James's wild buckwheat) and Paronychia jamesii (James's nailwort).

As determined by Goodman and Lawson (1995), Long's party crossed the 100th Meridian on August 18, 1820 and entered modern-day Ellis County in the area of
Antelope Hills. Their route across the state followed the Canadian River to its junction with the Arkansas River, which they then traveled down to Fort Smith, Arkansas and exited Oklahoma on September 13

(Figures 8, 9).

Figure 8 Western half of route of Long expedition through Oklahoma (Goodman and Lawson 1995). Courtesy of the University of Oklahoma Press.
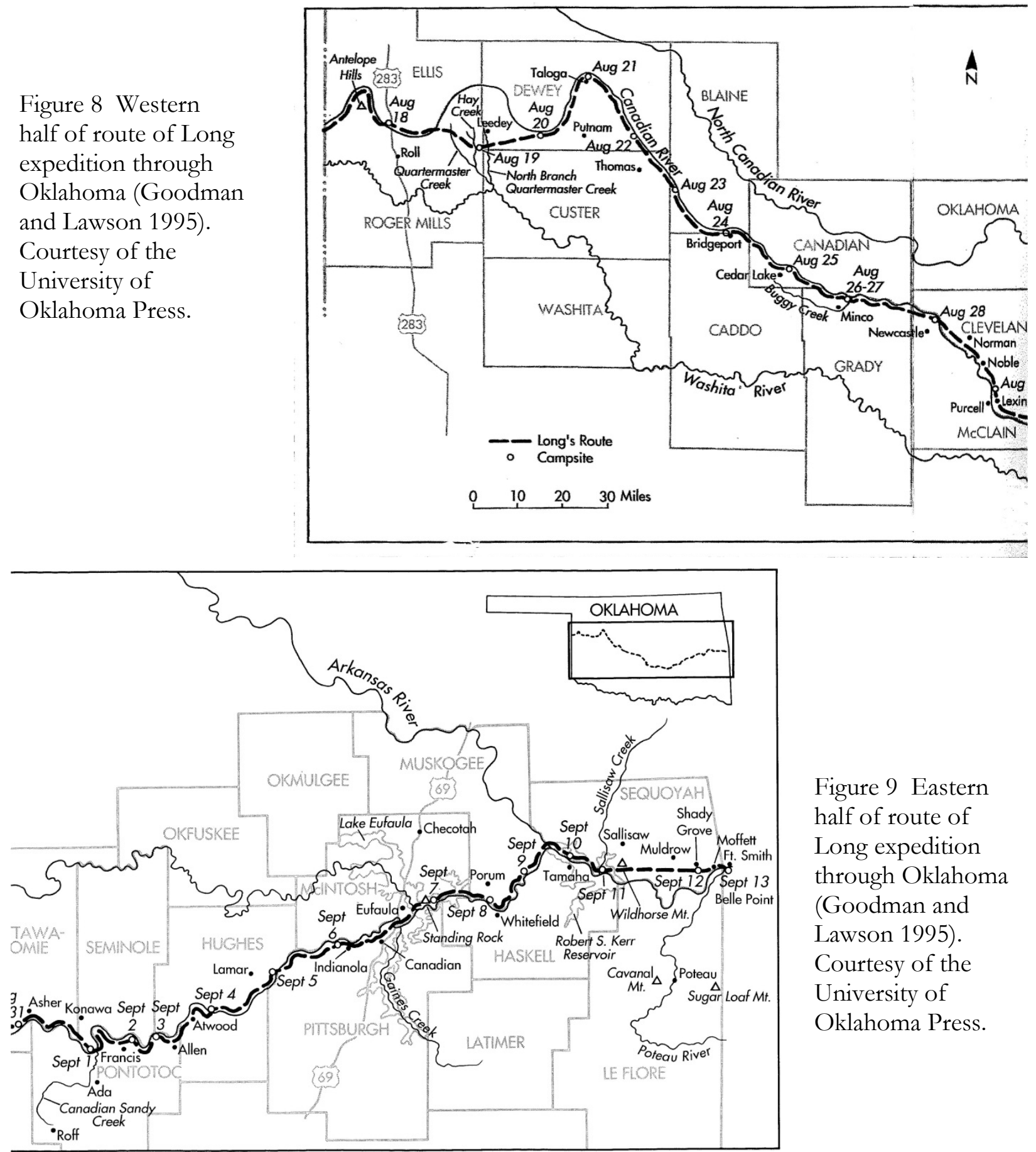

Figure 9 Eastern half of route of Long expedition through Oklahoma (Goodman and Lawson 1995). Courtesy of the University of Oklahoma Press.

Ronald J. Tyrl and Paula A. Shryock 
Goodman and Lawson (1995) provide the most comprehensive list of James's collections. Of the many species collected by James in Oklahoma, representatives familiar to ONPS members include the following: Cornus drummondii (rough-leaf dogwood), Asimina triloba (pawpaw), Plectocephalus americanus (basket flower), Elephantopus carolinianus (leafy elephant-foot), Monarda punctata (spotted beebalm), Cercis canadensis (redbud), Oenothera speciosa (pink ladies), and Nemastylis geminiflora (celestial lily)

\section{Washington Irving and Charles Joseph}

Latrobe-In 1832, Washington Irving, often described as America's first internationally known author, and Charles Latrobe visited Oklahoma and made observations of its flora and vegetation (Figures 10,11). Irving is, of course, best known for his short stories such as The Legend of Sleepy Hollow and Rip van Winkle, but he was also a prolific writer of essays, biographies, and travelogues (Thoburn and Wells 1955).

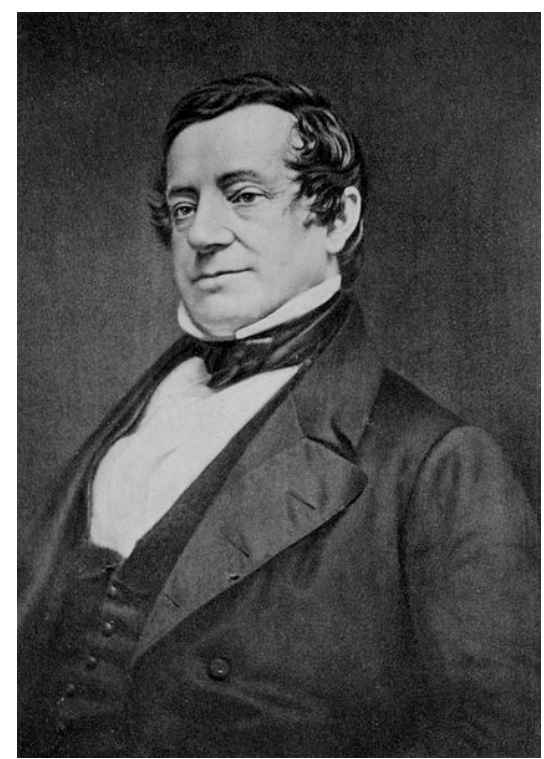

Figure 10 Washington Irving. Copy daguerreotype by Mathew Brady, reverse of original by John Plumbe, from U. S. Library of Congress's Prints and Photographs Division.
An Englishman, Latrobe was the first lieutenant-governor of the colony of Victoria in Australia and played an important role in the development of Melbourne's infrastructure (Wright and Shirk 1955). Of importance to us, is that he was also a naturalist, being interested in plants, geology, beetles, and butterflies.

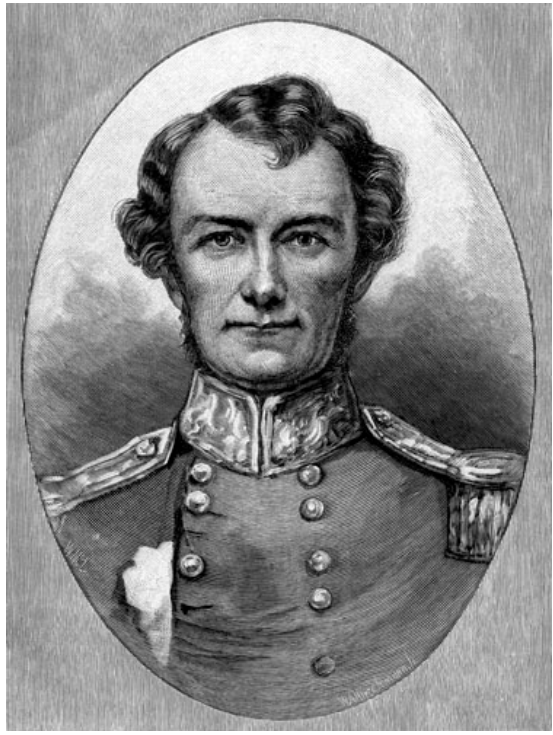

Figure 11 Charles Joseph Latrobe. Portrait from Royal Melbourne Hospital archives, Melbourne, Victoria, Australia.

Their trip to Oklahoma was the result of a series of fortuitous meetings. As described by McDermott (1944), Irving and Latrobe met and became friends while traveling by ship from Europe to New York early in the spring of 1832. They apparently regaled themselves with the possibility of visiting the Far West and engaging in buffalo hunts and other adventures. On a subsequent boat trip from Buffalo, New York to Detroit in August 1832, they by chance met Henry Leavitt Ellsworth. Appointed by President Andrew Jackson as one of three commissioners for Indian tribes in Arkansas and Oklahoma, he was on his way to Fort Gibson in Indian Territory and invited them to join him. His task was "...to study the country, to mark the boundaries, to pacify the warring Indians, and in general, to establish order and justice." (Williams and Simison 1937). 


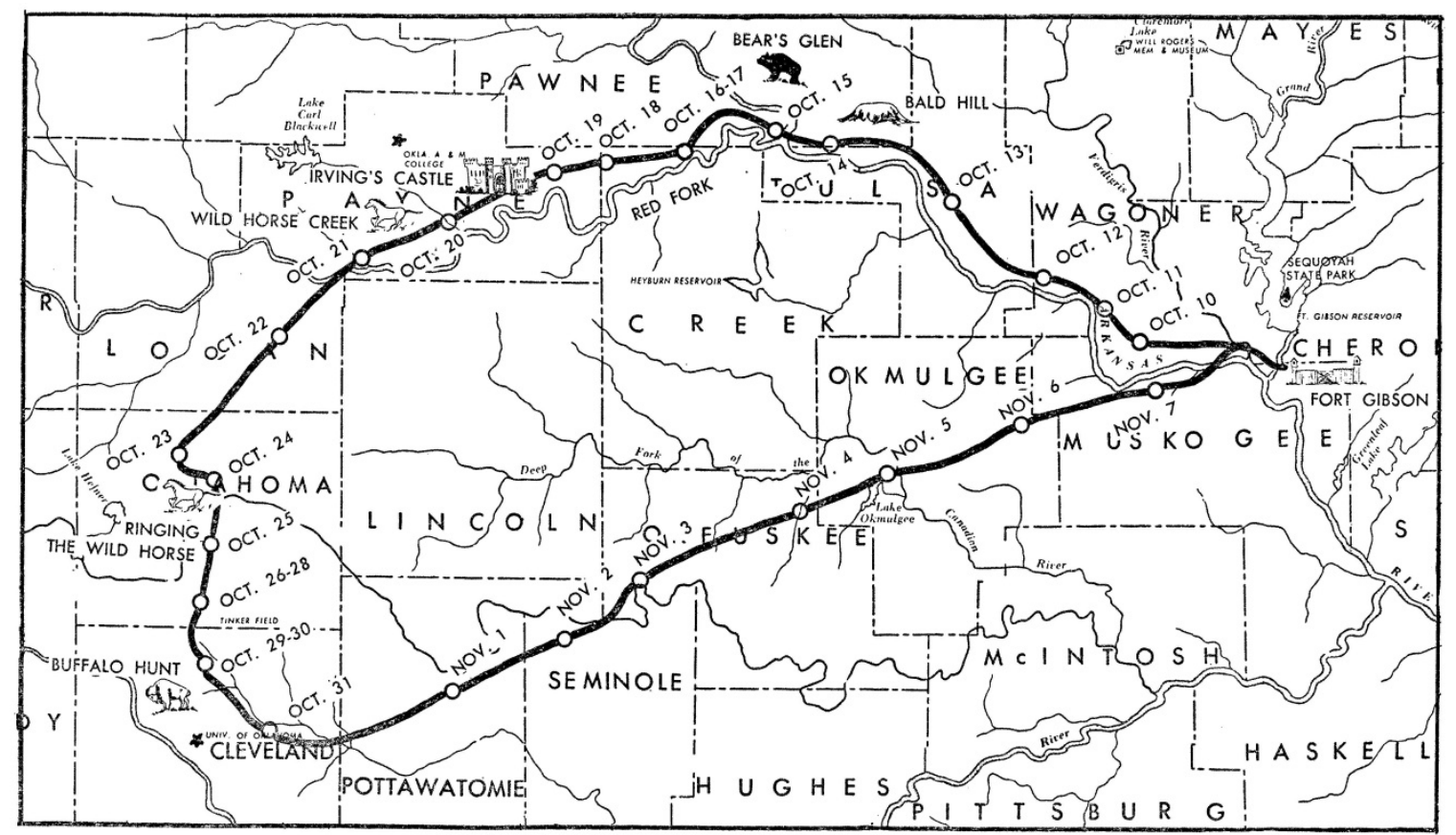

Figure 12 Route of the Ellsworth-Irving-Latrobe expedition through central Oklahoma (Wright and Shirk 1955).

When the three men arrived at Fort Gibson, Ellsworth discovered that there had been bureaucratic problems in communication. He wasn't expected, the other two commissioners and commission secretary hadn't arrived, and a military escort had been prematurely sent off, so no formal work could be done (McDermott 1944). He decided to lead an expedition into Indian Territory to examine the country for settlement by the Civilized Tribes being relocated from the East. He appointed Irving to serve as the expedition secretary. Although Irving was not the leader, this expedition is today commonly referred to as "Irving's Tour" or the "Irving Expedition," most likely because of his fame as an author (Wright and Shirk 1955).

On October 10, they left Fort Gibson and over the course of the next four weeks made a loop through central Oklahoma (Figure 12). Irving described this exploration in his book Tour on the Prairies, which was published in 1835. Latrobe's account of the journey, also published in 1835, appeared in the form of six letters in his book The Rambler in North
America. Ellsworth wrote just one, 116-page letter, dated November 17, 1832, to his wife telling her of his trip with Irving and Latrobe (Thoburn and Wells 1955). The letter was published in book form-W ashington Irving on the Prairie or A Narrative of a Tour of the Southwest in the Year 1832-by Williams and Simison (1937). It is a more straight-forward account of the trip, in contrast to the more literary style publications of his companions. Each gives details not found in the other two works, and one really needs to read all three accounts to gain a complete understanding of what occurred and what they saw.

The significance of this trip is not in the plants collected, but rather in their descriptions of the landscape through which they passed and their different interpretations of it. For example, after having traversed the Cross Timbers during a period of stormy weather, Irving and his companions emerged upon the tallgrass prairie near the Canadian River in the vicinity of Norman. Irving wrote in his journal: 
...we emerged towards mid-day from the dreary belt of the Cross Timber, and to our infinite delight beheld 'the great Prairie,' stretching to the right and left before us. We could distinctly trace the meandering course of the Main Canadian, and various smaller streams, by the strips of green forest that bordered them. The landscape was vast and beautiful. There is always an expansion of feeling in looking upon these boundless and fertile wastes, but I was doubly conscious of it after emerging from 'our close dungeon of innumerous boughs

In Letter XV, naturalist Latrobe described the Cross Timbers by writing:

The dark brown horizon which appeared before us as we emerged from the deep bed of the river was known to be the Cross Timbers, a broad belt of dwarf oak forest, rarely interrupted by prairie, extending across the country, from the Red Fork to the Great Canadian, in the direction of North and South. Its mean breadth, by the report of the Indians, was twelve or fourteen miles, and it was now our object to cross it in a south-westerly direction. None of our party I think will ever forget that hilly stony region with its almost impenetrable forest of the closest and harshest growth, whose low rugged branches black and hard as iron with the alternate extremes of frost and fire, cost us many a fierce scramble and struggle on our passage both to and from the Canadian.

In the Cross Timbers themselves, no animal but the bear could find sustenance. They were as, I have before said, composed entirely of oak, of which I enumerated seven distinct species, besides varieties; from the diminutive pin-oak, bearing acorns at two years growth, to the large-cupped burr-oak. Properly speaking there is no undergrowth but a coarse grass. From this ironbound region, we generally contrived to escape towards night-fall, and to seek for a resting place in one of those spots of verdure in the vallies where the fading green and yellow foliage of the cottonwood popular formed a pleasing contrast to the leafless oak, and held out promise of our obtaining the indispensable necessaries of wood and water.

Beside the above-mentioned popular, together with bickory, walnut and willows, and the black and honey locust, we found a rich under-growth of dogwood, persimmon, haws, vines with sweet and sour grapes-Chickasaw plums of various colours - sassafras, and abundance of green-briar or tear-blanket as it is familiarly called_besides sumac, the delight of the bear at this season.

\section{Thompson B. Wheelock, Nathan Boone,} and James W. Abert-Observations of Oklahoma's vegetation, albeit not always in great detail, were also made by officers on military expeditions through Indian Territory and surrounding areas. In the summer of 1834, First Lieutenant Wheelock kept an official journal (Wheelock 1834) of an expedition conducted by U.S. Army Dragoons under the command of Colonel Henry Dodge. They traveled in a loop from Fort Gibson, southwest to the Red River in Marshall County, west to the Wichita Mountains and North Fork of the Red River in Kiowa County, and back to Fort Gibson. As an aside, George Catlin, renowned for his paintings of Native Americans, accompanied the group and made numerous sketches and observations (Shirk 1950). Wheelock recorded his observations of the prairies, forests, and bottomlands through which the dragoons passed, in some instances noting the species. On June 28, he wrote: "...character of timber, in general, small-post oak and black jack, and some trees of Bois d'Arc, a wood valuable to Indians for bows - a yellow, elastic wood of great tenacity." $\mathrm{He}$, of course, was describing Maclura pomifera, a member of the Moraceae or mulberry family, also known as Osage orange, bowood, and hedgeapple.

The youngest son of the famous Kentuckian Daniel Boone, Nathan Boone was a career military man who had commanded one of the companies on the 1834 Dodge expedition and was the first commander of Fort Wayne on Spavinaw Creek in 
northeastern Oklahoma in 1838 (Fessler 1929; Foreman 1941). In 1843, he led a detachment of Dragoons from Fort Gibson, up the Arkansas River into central Kansas and back overland through western Oklahoma to the Cimarron River, before returning to Fort Gibson. In doing so, he visited the Great Salt Plains, the Glass Mountains, and the sand hills and dunes on the north sides of the Cimarron and Canadian Rivers. As Wheelock had done, Boone recorded his observations of the ecogeography and flora of the area. On May 19 in modern day Osage County, he recorded:

Noticed on the prairie the wild indigo with a blue, and also with a white flower; the sensitive plant, the polar plant, a rosin weed. This plant is a tall plant perhaps 7 feet high, with a fan-shaped leaf which ranges generally north and south, affording a tolerable compass to the traveler over the prairie. A quantity of rosin is secreted at each joint which might render its cultivation desirable; its taste is strongly resinous, and the horse is very fond of it.

Boone's "polar plant" is undoubtedly Silphium laciniatum, commonly known as compass plant because of the orientation of its large basal pinnatifid or laciniate leaves. His observations of how his horse relished eating it are also astute. It is highly palatable and avidly sought out by livestock. Its presence and relative abundance is a classic indicator of grazing pressure. His "wild indigo" with blue flowers is likely Baptisia australis, which occurs as either scattered plants or small, localized populations and is characteristic of the later stages of plant succession in tallgrass prairies, as is Silphium (Tyrl et al. 2008).

Like the Long Expedition of 1820, a reconnaissance expedition led by Lieutenant Abert in 1845 traversed the state from west to east along the Canadian and Washita Rivers through lands occupied by the Kiowa and Comanche Indians (U.S. Senate 1846). As Everett noted (2009), he kept a journal of his observations in which he described and profusely illustrated the ecogeography, flora, and fauna of the area. In addition, he surveyed the locations of timber, water, and prairie grass, often including their exact latitude and longitude. His description of the sand dune belts on the north sides of the rivers illustrates the detail of his observations. His September 20 entry says:

To the southeast we traced the river by the high ridge of land which loomed up through the haze. Its bed spreads out to the width of 300 or 400 yards, and, being composed of deep sands, so absorbs the water that nothing can be discovered but a mass of fine, white silicious particles moving in the breeze... The strong wind heaps the sand upon the banks, forming constantly changing billocks and often advancing inwards like the dunes on the seacoast. The course of the streams may be traced for miles on a windy day, by the drifting clouds of sand which hang over their beds... Today we found plenty of the oak and cotton-wood. The bottoms were filled with grape vines and plum trees, and we passed several groves of hackberry; and the plains were varied with a beautiful species of 'Labiatae'.

Samuel Washington Woodhouse-Serving as both a surgeon and naturalist, Samuel Woodhouse (Figure 13) was one of several acting-assistant surgeons in the army who accompanied expeditions exploring the continent's interior and surveying potential railroad routes west (Ewan 1950). In 1849 and 1850, he was a member of two expeditions conducted by the U.S. Army Corps of Topographical Engineers sent to survey and mark the north and west boundaries of the Creek Nation in Indian Territory. Brevet Captain Lorenzo Sitgreaves led the first survey, and First Lieutenant Israel Woodruff led the second. Their surveys are often referred to as the Creek Boundary Expedition or the Sitgreaves-Wodruff Expedition (Figures 14-16). 


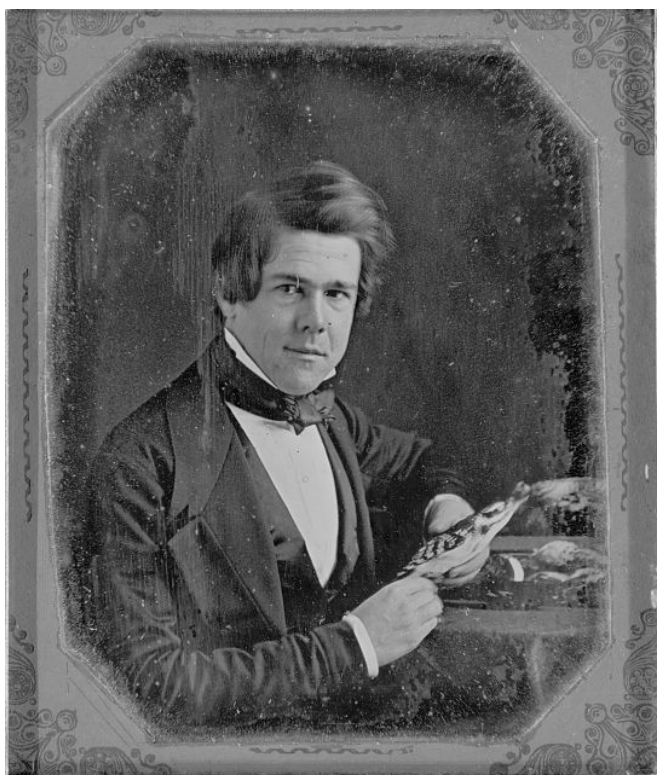

Figure 13 Samuel Washington Woodhouse in 1847. United States Library of Congress Prints and Photographs Division.

A member of the Academy of Natural Sciences of Philadelphia, Woodhouse was a true naturalist who collected plants, mammals, birds, reptiles, insects, and mollusks and deposited them in the Academy's museum in which he worked (Tomer and Brodhead 1992). In each of these groups, he discovered and described species new to science. The specific epithet woodhousei used for species of birds, toads, snakes, tree-borers, and plants honors him. Woodhouse collected 709 plant specimens on the first trip and 757 specimens on the second; albeit many were duplicates. His journals contain numerous entries about his collecting, pressing, and identifying the plants. As other early surgeon-botanists in Oklahoma did, he eventually submitted his plants to John Torrey to verify their identity. Many are now deposited in the herbarium of the New York Botanical Garden (Tomer and Brodhead 1992). His reports of the natural history of the two surveys were incorporated in Sitgreaves's and Woodruff's official reports, finally published together in 1858 (U.S. House of Representatives 1858). Woodhouse (1852) also wrote an unpublished summary of the two expeditions.

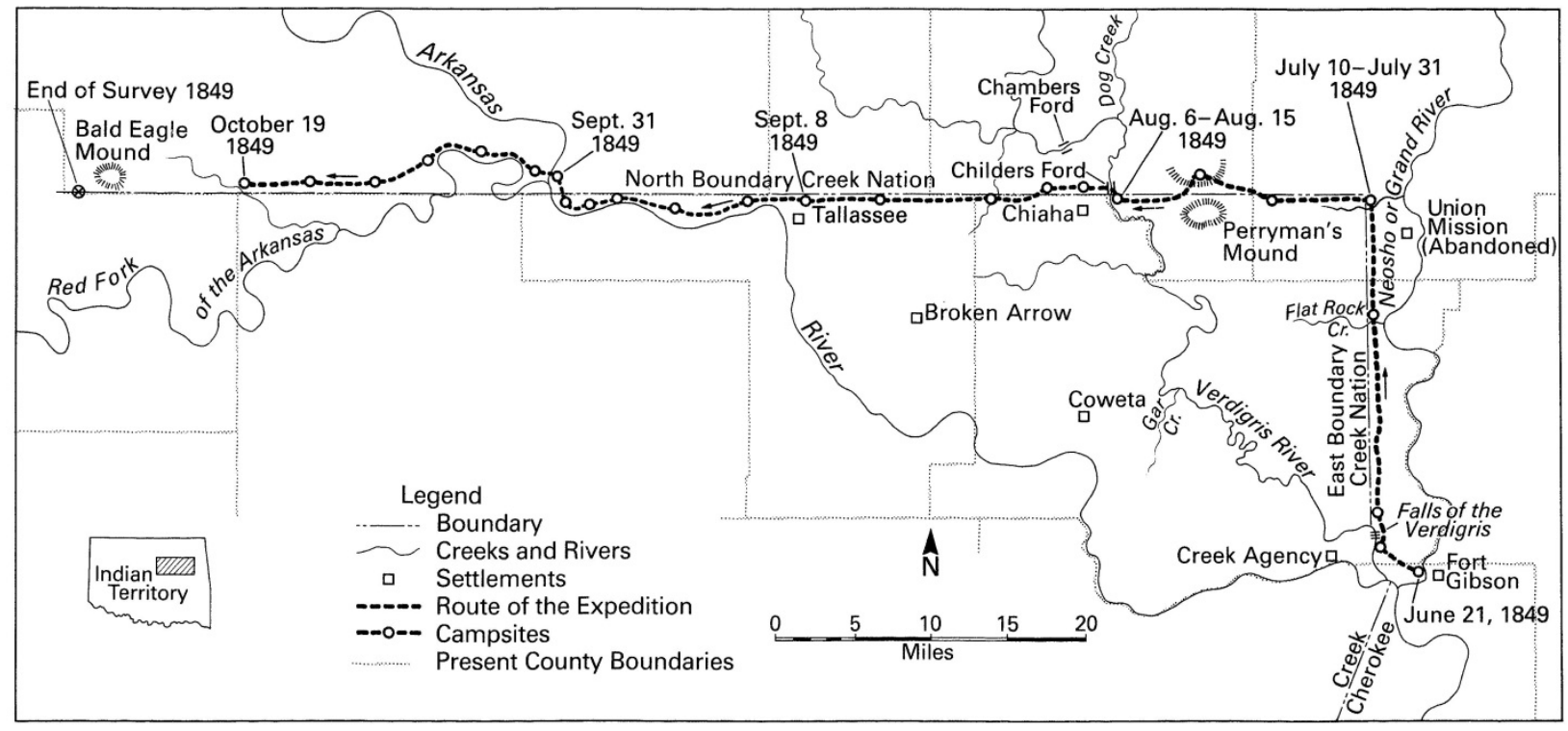

Figure 14 Route of the first Creek Boundary Survey Expedition, June 21 to October 19, 1849. Map drawn by Bill Nelson (Tomer and Brodhead 1992). Courtesy of the University of Oklahoma Press. 


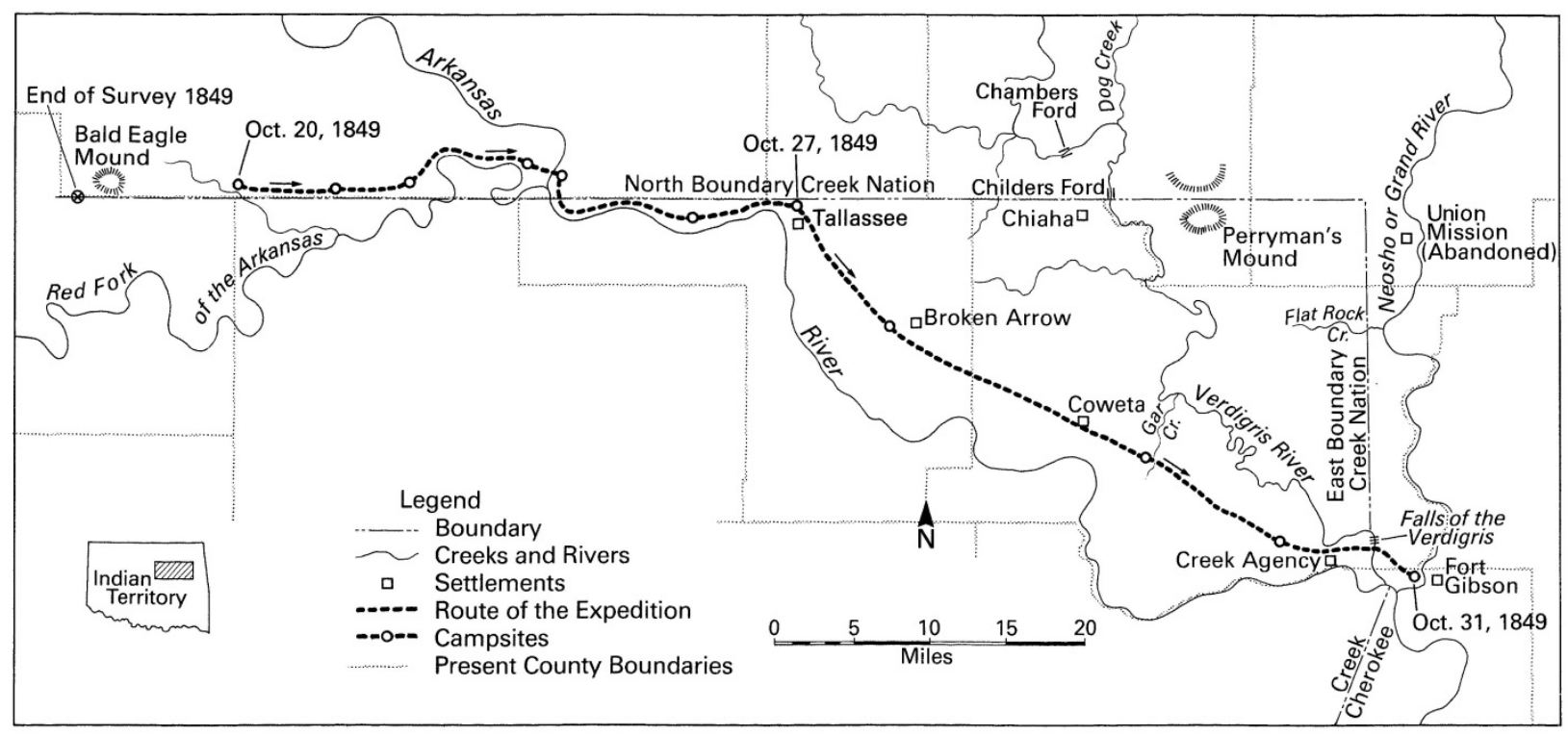

Figure 15 Route of the first Creek Boundary Survey Expedition, October 20 to November 1, 1849. Map drawn by Bill Nelson (Tomer and Brodhead 1992). Courtesy of the University of Oklahoma Press.

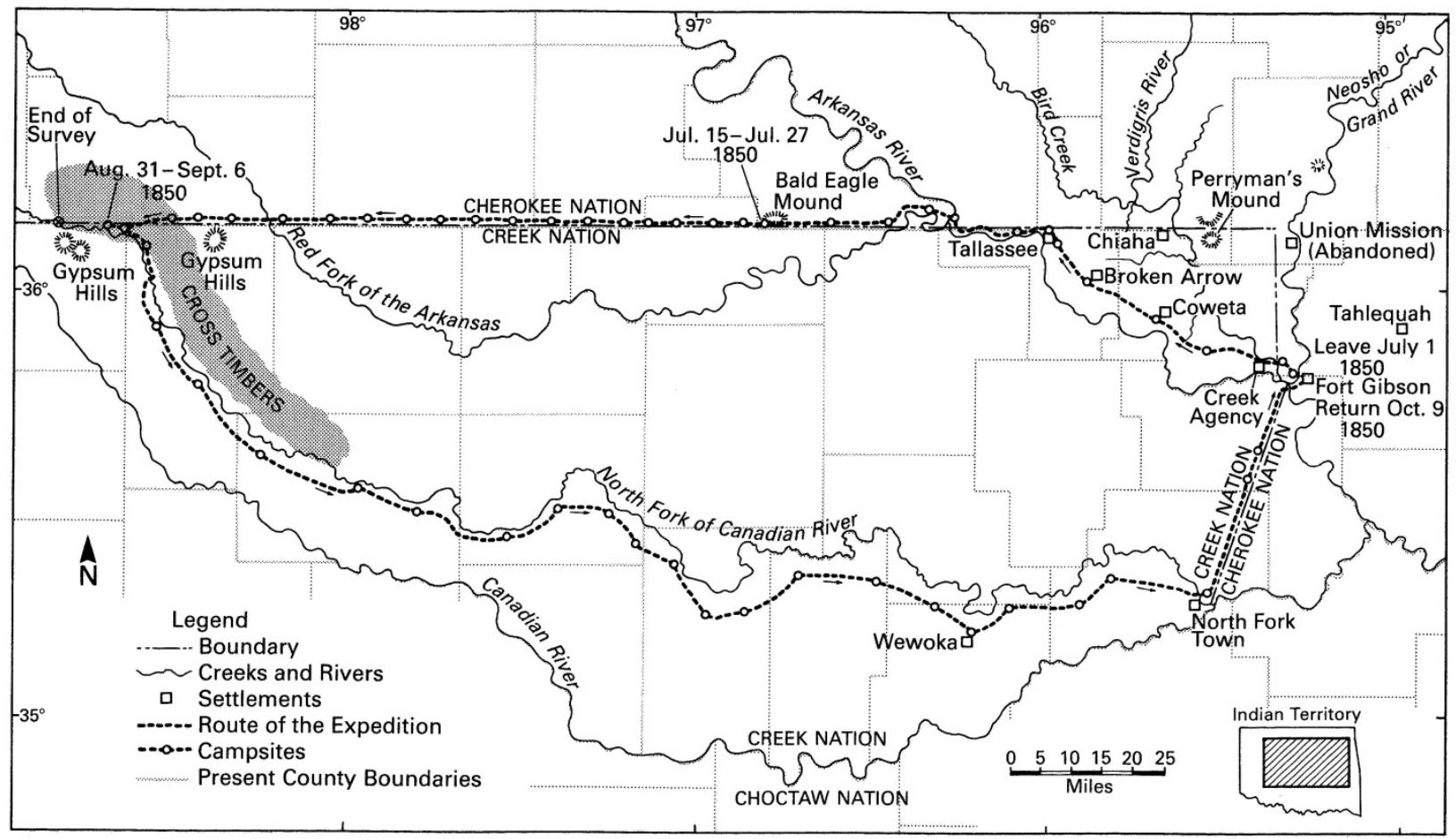

Figure 16 Route of the second Creek Boundary Survey Expedition, July 1 to October 9, 1850. Map drawn by Bill Nelson (Tomer and Brodhead 1992). Courtesy of the University of Oklahoma Press. 
George Getz Shumard-Both a surgeon and a geologist, George Getz Shumard was a member of the (Captain R.B.) Marcy

Expedition assigned the task of finding the source of the Red River in the summer of 1852. In addition to collecting rocks, minerals, soils, fossils, and shells, Shumard collected about 200 species of plants, half of which were collected within the boundaries of modern day Oklahoma (Winkler 1915; Jeffs and Little 1930). He sent his collections to John Torrey who determined their identities and had some of the rare ones illustrated. The list of Shumard's plants appears in Marcy and McClellan's report to Congress (U.S. Senate 1853). Representative species familiar to ONPS members are Tephrosia virginiana (goat's rue), Rhus aromatica (lemon sumac), Polygala alba (white milkwort), Callirhoe involucrata (purple poppy mallow), and Pediomelum esculentum (breadroot scurf-pea).

As an aside, it is interesting to note that Shumard also collected the first fossil described in modern day OklahomaGoniatites choctawensis, an ammonite characteristic of the late Middle Mississippian. As the specific epithet implies, it was discovered in the Choctaw Nation in Pittsburg County near the now defunct settlement of Brushey (Branson 1959). Marcy's expedition explored the Red River and its North Fork from the mouth of Cache Creek in Cotton County to the 100th Meridian on the western edge of modern Beckham County (Dale and Rader 1930). In his report (U.S. Senate 1853), he recorded his observations of the surrounding landscape. On May 18, he wrote:

As we advance, the country, away from the borders of the water-courses, becomes more barren, and woodlands are less frequently met with; indeed, upon the river there is no other timber but cotton wood (Populus angulata,) and elm (Ulmus americana) and these in very small quantities; for the most part the valley of the river along where we passed to-day is entirely destitute of trees.
On May 22, he and his party followed a tributary of the Red River and wrote:

This stream, which I have called Otter creek, (as those animals are abundant here,) rises in the Wichita Mountains, and runs a course south 25 degrees west. There are several varieties of wood upon its banks, such as pecan, black walnut, white ash, elm, hackberry, cotton-wood, wild china, willow, and merquite; and among these I noticed good building timber. The soil in the valley is a dark loam and produces a heavy vegetation.

As had Juan de Oñate and George C. Sibley before him, Marcy recorded his pleasure in eating the native plums and grapes. On May 29, he wrote:

We find blackberries, raspberries, gooseberries, and currants growing upon the mountains; and this is the only locality west of the Cross Timbers where I have seen them. Grapes and plums are also abundant here, as elsewhere, upon Upper Red river. The grapes are rather smaller than our fox grapes, are sweet and juicy when ripe, and I have no doubt would make good wine; they grow upon small bushes about the size of currantbushes, standing erect like them, and are generally found upon the most sandy soil, along near the borders of the streams. The plums also grow upon small bushes from two to six feet high, are very large and sweet, and in color vary from a light pink to a deep crimson; they are the Chicasaw plum, (Prunus chicasa $[=P$. angustifolia $]$ ).

John Milton Bigelow-The military expedition of Lieutenant Amiel Weeks Whipple to survey a potential route for a transcontinental railroad in 1853 was also accompanied by a surgeon-botanist. Following the route explored by Marcy, the survey party passed through central Oklahoma, and Dr. John Milton Bigelow collected about 125 species within the state (Featherly 1943). As had Shumard, he sent his specimens to John Torrey for identification (Torrey 1856). In addition to collecting plants, he made detailed observations of the 
ecogeography of the passing landscape and eventually created a hypothetical line transect of the vegetation types from the Mississippi River to the Pacific Ocean (Featherly 1943). The plants he collected and his observations were published in five parts as part of the "Whipple Report" in 1856 (U.S. Senate 1856). The significance of his work is perhaps best illustrated in Torrey's introduction to his part of the "Report":

His ample collections were brought home in perfect order, and the following report affords abundant proof of the zeal and success with which be labored. A number of new genera and more than sixty new species have been discovered by $D r$. Bigelow and he has added much valuable information upon many heretorfore imperfectly known plants.

In a letter written to Asa Gray in July 1854 as he was working on Bigelow's plants, Torrey wrote that Bigelow's collection was “...twice as large as Beckwith's and Pope's [collectors with other survey parties] put together..." and that the quality of the pressed plants was such that they were “... a pleasure to study." (Waller 1942).

Bigelow is honored by numerous species with the specific epithet bigelovii, including two Oklahoma species: Poa bigelovii (Bigelow's bluegrass) and Bidens bigelovii (Bigelow's beggarticks). An interesting aside is that he made the first collection of guayule, a shrubby member of the Asteraceae or sunflower family, subsequently described and named Parthenium argentatum by Asa Gray (Waller 1942). During World War II, it was extracted from Hevea trees in Southeast Asia and used as a substitute for rubber. Today it is a source of hypoallergenic latex for medical devices and a potential source of biofuel.

Timothy E. Wilcox-In 1875-1877, "several hundred" species were collected in western Oklahoma by Wilcox, an Army surgeon and botanist. The plants he collected were identified by Alphonso Wood, the author of several botany textbooks widely used in the 1800s. Among the Wilcox collections was a plant that Wood thought was new to science. When he published (1878) his list of Wilcox's species, Wood named it Grindelia nuda (curlytop gumweed). However, today it is considered (Strother and Wetter 2006) to be conspecific with $G$. squarrosa (curlycup gumweed).

George Dexter Butler-Although trained as a lawyer and admitted to the bar in Iowa, George Butler became a teacher in the state of Arkansas and in Indian Territory (Jepson 1928). He began collecting plants primarily in Atoka County and in particular in the Limestone Gap area, with most of his specimens collected in 1877 . He sent his plants for verification of his identifications to George Engelmann in St. Louis, with whom he had been corresponding, and in 1878 published his species list (Butler 1878). Of interest is his recognition that he had encountered a new species of Isoëtes (quillwort). Engelmann honored him with the binomial I. butleri Engelm. (Engelmann and Butler 1878). Butler subsequently moved to California where he began collecting plants in the Siskiyou Mountains. He eventually made one of the most comprehensive inventories of the mountains, with his specimens being cited by many other taxonomists (Jepson 1928).

\section{Mark Alfred Carlton and Charles Stiles} Shelton-An additional 400 species were collected in 1891 by Carlton and Shelton in the Indian and Oklahoma Territories. A list of them was published by J.M. Holzinger in 1892. A botanist at the Kansas Agricultural Experiment Station and later the first president of the American Society of Agronomy, Carleton collected plants from mid-April through September in an area bounded by the Arkansas and Canadian Rivers and the Arkansas, Colorado, and New Mexico borders. In this publication (Carleton 1892), he described the plants characteristic of different ecogeographic conditions_-sandy 
soils, gypsum hills, salt marshes, and sandstone outcrops.

As a plant collector for the U.S. National Museum of Natural History, Shelton spent his time in the southern half of the state, from the Sans Bois Mountains in Latimer County through McAlester, Stonewall, Caddo, and Colbert, west to Anadarko, the Washita River, Cache, and the Wichita Mountains (Holzinger 1892).

Ernest Everett Bogue-After completing his undergraduate work in horticulture and forestry and graduate work in botany and entomology, Ernest Bogue (Figure 17) became head of the Department of Botany \& Entomology at Oklahoma Agricultural \& Mechanical College (OAMC) in 1896. During his four-year tenure, he published Weeds of Oklahoma (1899), Native Oklahoma Plants (1900a), and An Annotated Catalog of the Ferns and Flowering Plants of Oklahoma (1900b).

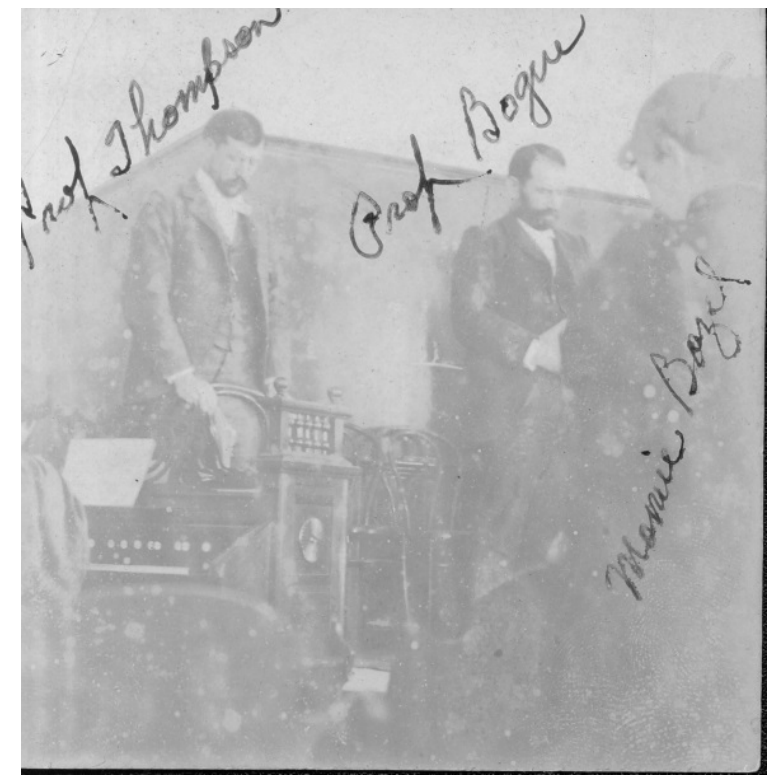

Figure 17 Ernest Everett Bogue. Photo courtesy of the Special Collections and University Archives, Edmon Low Library, Oklahoma State University.

His publication on weeds was an update of an 1895 bulletin by James Neal that listed more than 70 weeds classified by Neal as "aggressive," "timid," or “occasional." In his edition, Bogue wrote synopses of the morphology and problems characteristic of each weed and illustrated them with line drawings and photographs. He declared Ambrosia psilostachya (western ragweed) to be the state's worse weed, followed by Solanum rostratum (buffalo bur) and Digitaria sanguinalis (crabgrass). He also commented on the need for weed control by writing: "Too many farmers in the Territory are neglecting the weed question. The rich new soil is not very foul until crops have been grown for a few years."

In his OAMC bulletins (1900a, 1900b) on Oklahoma's native plants, Bogue gave “...the scientific and common names of and notes on about 750 plants growing without cultivation in the territory." This list was based on four years of plant collecting by Bogue and those supervised by him. He did not include species from Indian Territory because he thought he had insufficient information (1900b). In Native Oklahoma Plants (1900a), he gives an overview of the ecogeography of the areas in which he collected and makes observations about the ecology of various species. These observations, like those of his predecessors, give us an idea of what the state was like in the early years of settlement by Europeans.
Albert Heald Van Vleet-Most visitors strolling the Van Vleet Oval on the University of Oklahoma's campus are likely unaware of the many accomplishments of the man for whom the mall is named. Van Vleet (Figure 18) was the university's first faculty member to have a doctorate, the first head of its Department of Biology (1898), the first dean of its Graduate College (1909), and the first Territorial Geologist and Chief of the Territorial Geological and Natural History Survey(1899)( Wardner 1939; Goodman and Lawson 1978). The Department of Biology evolved into the Departments of Zoology, Botany and Microbiology, and Geology; whereas, the Survey gave rise to the modern Oklahoma Geological Survey and Oklahoma Biological Survey. 
He believed that the university should have a complete collection of the plant and animal life of the territory and state, and in 1900 he began taking collecting trips throughout the territory. He published his $A$ List of the Ferns and Flowering Plants of Oklahoma (1901) and Plants of Oklahoma (1902), the latter listing 838 species as present in the university herbarium (Jeffs and Little 1930; Goodman and Lawson 1978). Unfortunately, a disastrous fire on January 6, 1903 destroyed much of the university, including the herbarium. Van Vleet began collecting anew, only to have most of his new collections burned in a second fire in 1907. Goodman and Lawson (1978) provide itineraries of his collecting trips in 1900, 1903 after the fire, and 1905.

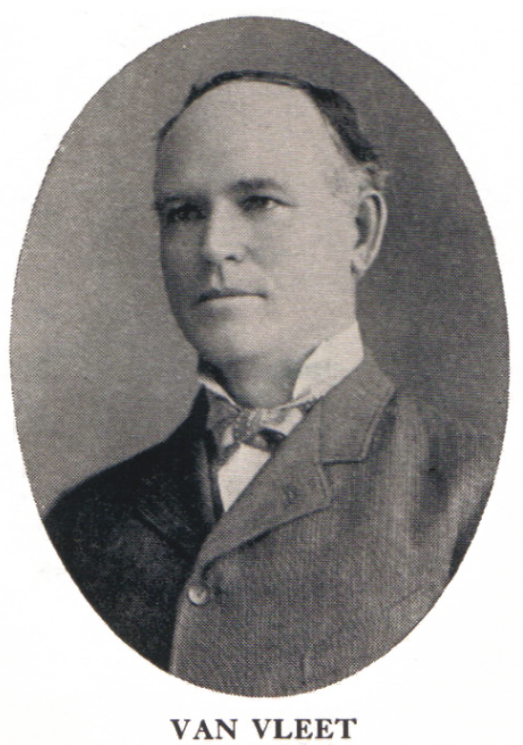

Figure 18 Albert Heald Van Vleet. Portrait from 1916 Sooner Yearbook, University of Oklahoma.

George Walter Stevens-We traditionally cite the doctoral dissertation of George Walter Stevens (Figure 19) as the first formal taxonomic study of the state's plants. In 1903, he became the head of the biology department at the State Normal School, now
Northwestern Oklahoma State University. In addition to being a dynamic teacher, he was an avid plant collector, and it is said that he always planned his vacations with the objective of exploring some new region of Oklahoma and other states (Henson 1941).

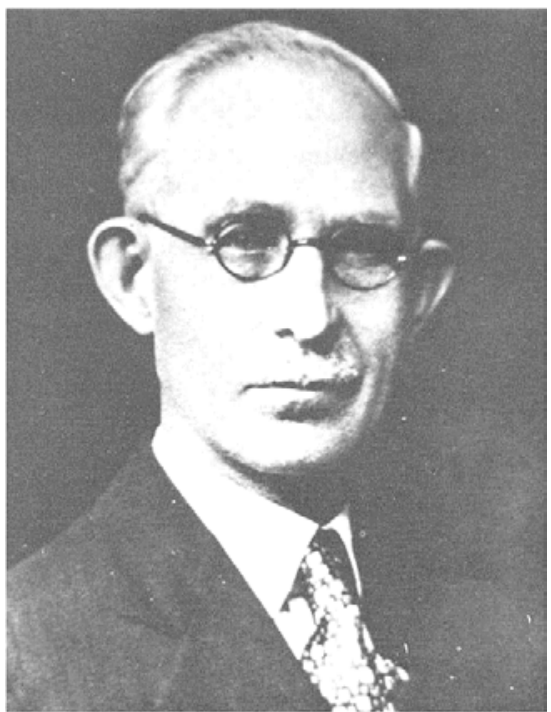

Figure 19 George W. Stevens (Goodman et al. 1978). Photo courtesy of Anna B. Fisher and Oklahoma Academy of Science).

In 1913, he was appointed the Director of the State Botanical Survey and during the growing season of that year was in the field almost continually on collecting trips throughout the state (Figures 20-24). Goodman and coworkers (1978) noted that Stevens was probably the first individual to collect plants in Red Rock Canyon near Hinton in Caddo County, the secondfollowing M.A. Carlton in 1891-to collect near Black Mesa in Cimarron County, and the third to collect at the Glass Mountains near Orienta in Major County and the Great Salt Plains near Jet in Alfalfa County-after Carlton in 1891 and Van Vleet in 1900. 


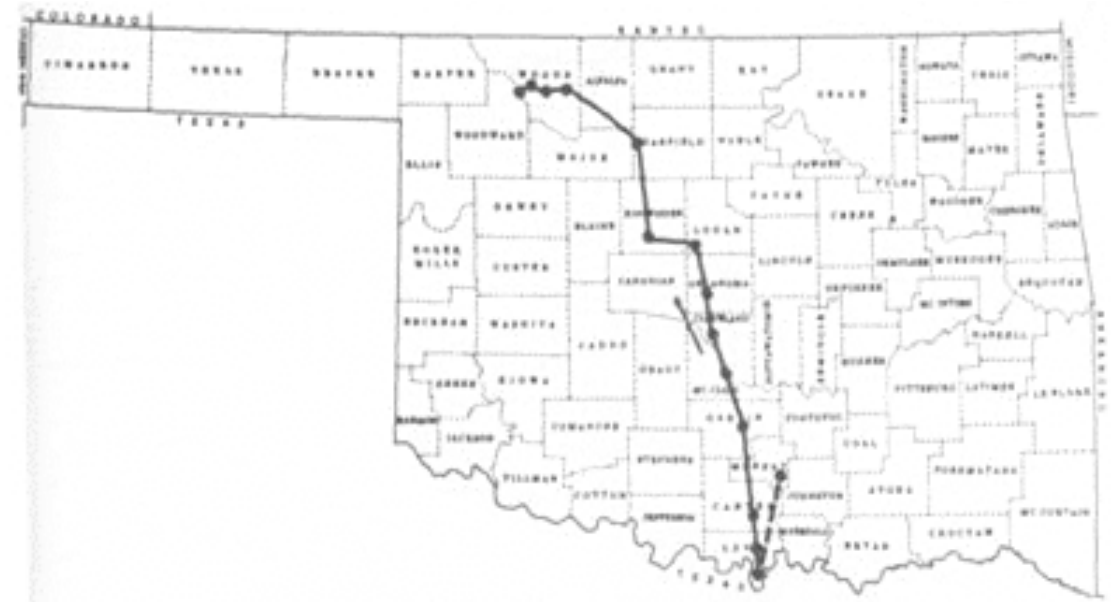

Fucurx 2. Roote of Servens' collecting trip in April, 1913.

Figure 20 Route of collecting trip of G.W. Stevens in April 1913 (Goodman et al. 1978). Courtesy of Oklahoma Academy of Science.

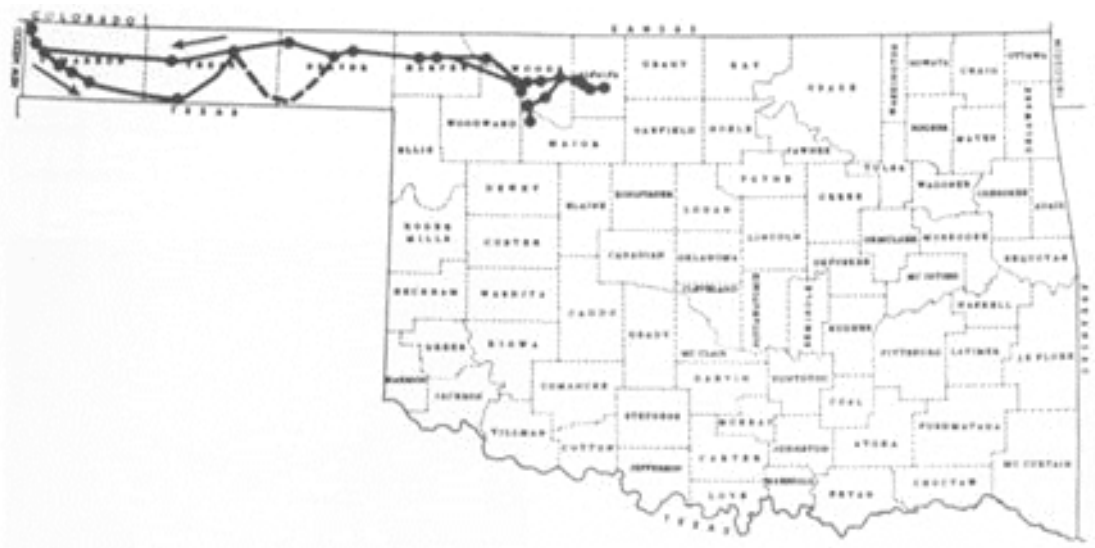

FiGue 3. Route of Stevens' collecting trip in May, 1913.

Figure 21 Route of collecting trip of G.W. Stevens in May 1913 (Goodman et al. 1978). Courtesy of Oklahoma Academy of Science.

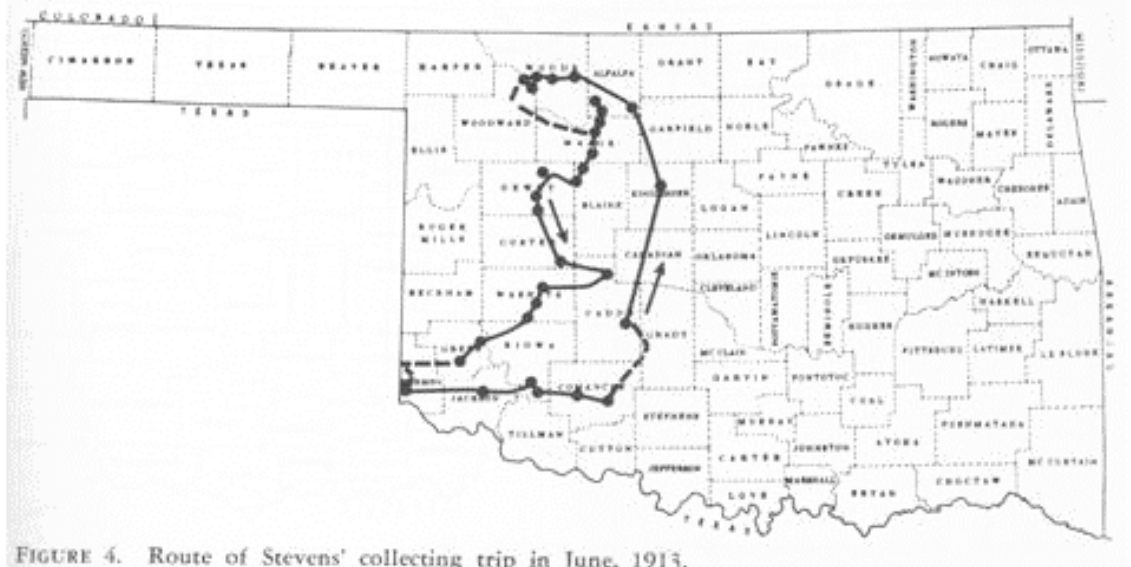

Figure 22 Route of collecting trip of G.W. Stevens in June 1913 (Goodman et al. 1978). Courtesy of Oklahoma Academy of Science. 


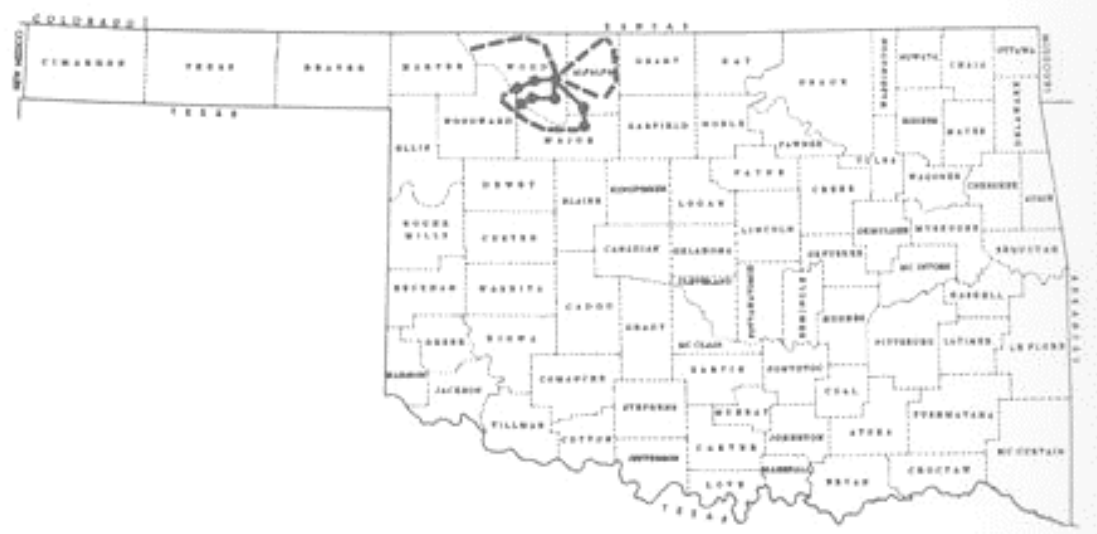

Fucurr 6. Route of Stevens' collectipg trips in July, 1913.

Figure 23 Route of collecting trip of G.W. Stevens in July 1913 (Goodman et al. 1978). Courtesy of Oklahoma Academy of Science.

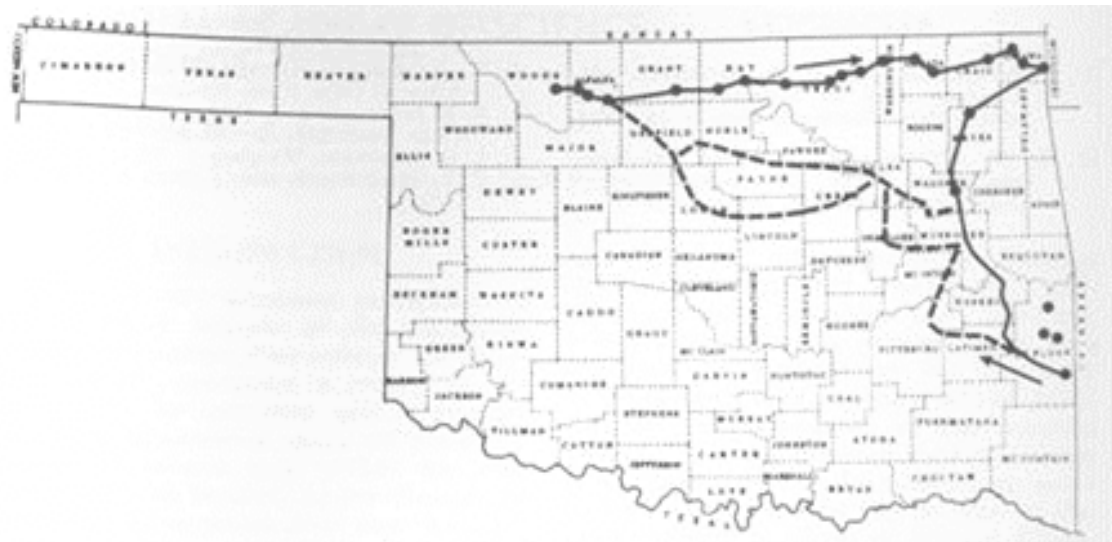

Floure 7. Route of Stevens' collecting trip in August and September, 1913.

Figure 24 Route of collecting trip of G.W. Stevens in August and September 1913 (Goodman et al. 1978). Courtesy of Oklahoma Academy of Science.

With the exception of the extreme southeast corner, Stevens traversed the state, accumulating thousands of specimens which were deposited in the herbaria at the University of Oklahoma, Oklahoma State University, and Harvard University. In addition, many specimens were distributed through herbarium exchange programs to herbaria elsewhere in the United States and world. Indeed, his distinctive labels (Figure 25) are encountered everywhere. While working in the herbaria at the Royal Botanic Gardens in England and Australia, Tyrl encountered his specimens.

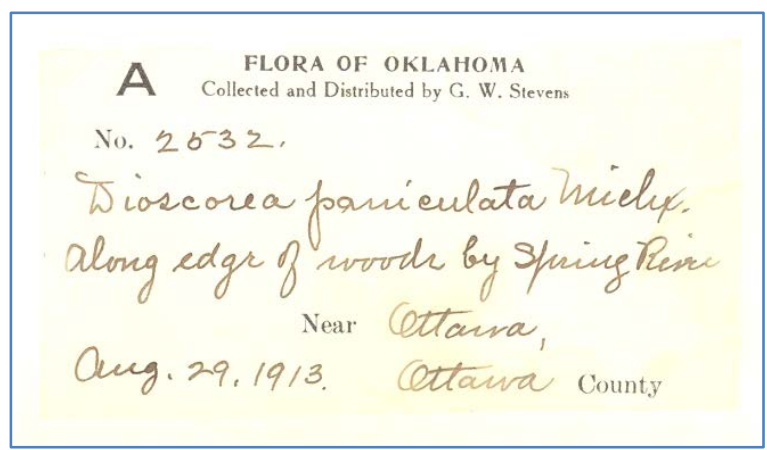

Figure 25 Herbarium specimen label of G.W. Stevens collection 
The plants collected by Stevens and other collectors (several of them former students) were the basis of his Harvard University 1916 doctoral dissertation titled The Flora of Oklahoma. Never formally published, this Flora included keys and generic descriptions but lacked descriptions for the more than 1,600 species included in it (Goodman et al. 1978). He did comment on the abundance and distribution of several species. When he defended his dissertation, he was introduced to the examining committee by a Professor Robinson, who said (Henson 1941):

Gentlemen, this candidate, $M r$. George Walter Stevens, whom I present from my department is the most versatile candidate that I have ever presented before this board-indeed, the most versatile man along scientific lines that I have ever known.

Today, Stevens in honored by Nama stevensii (Steven's nama or Steven's fiddleleaf), a gypsophilic species in the Hydrophyllaceae encountered in the Cimarron, Weatherford, and Magnum Gypsum Hills geomorphic provinces of the state.

William Christopher Prier-A professor and eventual head of the biology department at Northeastern State College in Tahlequah, Prier was an avid collector of the grasses and plants of the Cherokee Hills (Henson 1941). His master's thesis (1923a) and a derived publication (1923b) were on grasses; his collection, the most complete for the state at the time of his death in 1927, was purchased by OAMC and deposited in the college's herbarium (Featherly 1943). For some reason, he reversed the initials in his professional name, and thus his publications and distinctive herbarium labels bear the name "C.W. Prier."

Louis Herman Pammel—Perhaps best known for his Manual of Poisonous Plants (1911), Louis Pammel made three visits to Oklahoma in 1888, 1921, and 1929 (Featherly
1943). After his second visit, he wrote a short report titled $A$ Day Near Muskogee Oklahoma (1923) in which he enumerated the species collected in the bottomlands and uplands and the new introduced species not present in 1888. He also described the changes in Muskogee as a city and the appearance of the nearby Canadian and Arkansas Rivers and limestone bluffs.

Royal Edgar Jeffs - Although trained as a plant physiologist at the University of Iowa, Royal Jeffs made a contribution to our knowledge of the flora as curator of the herbarium at the University of Oklahoma, 1925 to 1933 . He made numerous collecting trips with Albert Van Vleet and his students, including Elbert Little (Henson 1941). In 1930, he and Little published a checklist of the state's ferns and seed plants, which listed 1,944 species and was based on their collections, the unpublished dissertation of G.W. Stevens (1916), and H.I. Featherly's (1928) checklist of Oklahoma's grasses. Of interest are their discussions of areas in the state to be searched for new species, distributional ranges of various species to be clarified, and the need for detailed studies of county floras. Jeffs subsequently published (1931) a key to the species of the checklist, with the exception of the grasses and sedges.

\section{Thomas R. Stemen and W. Stanley} Myers-As science teachers at Central High School in Oklahoma City, Thomas Stemen and Stanley Myers felt the need to have a manual for the identification of plants to be used by students in their biology and botany classes. In 1929 they published Spring Flora of Oklahoma with Key in which they described 90 families, 265 genera, and 476 species. This book was followed in 1937 by Oklahoma Flora, which encompassed 147 families, 640 genera, and 1,626 species, plus illustrations and abbreviated morphological descriptions. Unfortunately, they did not include the grasses, sedges, and rushes - a significant segment of the state's flora comprising 
approximately 116 genera and 534 species (Tyrl et al. 2010). This omission is somewhat surprising because Featherly (1928)noted in his checklist of grasses that they had made extensive collections of grasses in the Oklahoma City area. The book was severely criticized (Fernald 1938) for the absence of the graminoids and problems in taxonomic concepts, nomenclature, and key construction. However, despite its shortcomings it does represent the first attempt to make identification of Oklahoma's plants easy for the layman.

Arthur Irving Ortenburger-Although referred to as the "Father of Oklahoma Herpetology" and a faculty member in the Department of Zoology at the University of Oklahoma, Arthur Ortenburger extensively collected plants throughout the state while conducting a series of expeditions for the University of Oklahoma Biological Survey in the 1920s and 1930s (Carpenter 2000). He documented (1928a, 1928b) the plants he encountered on several of his trips.

Robert Bebb-Robert Bebb (Figure 26) was a grain receiver's agent in Illinois prior to his purchase of a floral business in Muskogee in 1910. Quite an accomplished businessman, he was also an avid botanist and naturalist. Most of his spare time was spent in botanizing and identifying plants (Foreman 1942). After his retirement from the floral business in 1936, he botanized full-time primarily in eastern Oklahoma, but also in Illinois, Indiana, Minnesota, Texas, California, and the Rocky Mountains (Hopkins 1943a).

He corresponded with and sent specimens to botanists and herbarium curators throughout the country including those at the U.S. National Herbarium, the Gray Herbarium, various state universities, and especially the University of Oklahoma where he formed a close friendship with Milton Hopkins who was curator of the herbarium (Foreman 1942). On June 5, 1939, George Lynn Cross, the head of the Department of

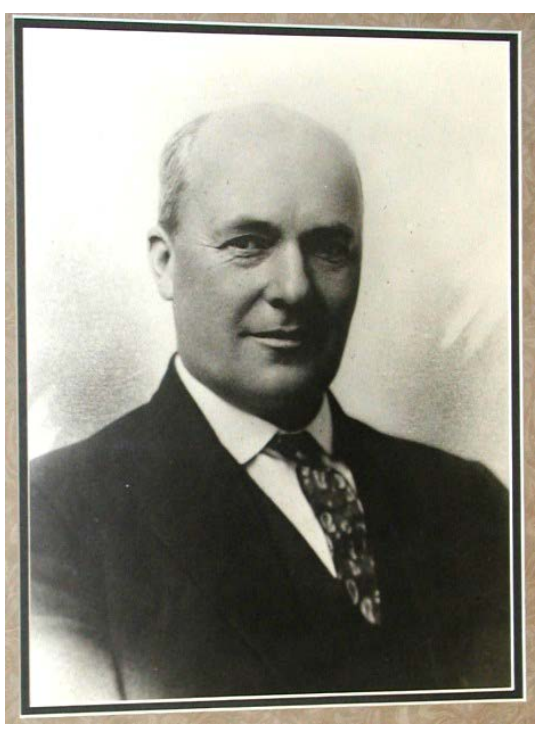

Figure 26 Robert Bebb. Photo courtesy of Wayne Elisen, Bebb Herbarium, University of Oklahoma.

Botany at the University of Oklahoma, wrote Bebb saying:

The entire eastern part of the state is rich floristically.... and collections from [the area are] sparse, so that anything that you can contribute to our knowledge of the flora of those counties will be most acceptable.

Bebb certainly took Cross at his word and amassed a private herbarium of approximately 30,000 specimens which he subsequently willed to the University. On May 5, 1942, the university's regents renamed the herbarium in his honor (Hopkins 1943b). Bebb's

collections were especially valuable at the time because they came from an area of the state which been little botanized, extended the ranges of plants into new regions, and included species previously unknown in the flora or not previously found south of the Ozark Highlands in Missouri and Arkansas (Foreman 1942).

William E. Bruner-The first formal classification of Oklahoma's vegetation was published (1931) by William Bruner, an ecologist. A Nebraskan, he taught in the 
Department of Botany at the University of Oklahoma for four years (1922-1926) after earning his masters degree. Returning to Nebraska to work on his doctorate, he published a detailed description of Oklahoma's ecogeography-geology, soils, climate-and the plant associations present. The William E. Bruner Hall of Science on the campus of the University of Nebraska at Kearney honors him.

\section{William Franklin Blair and Theodore} Huntingon Hubbell-Although W. Blair was a mammalogist and T.H. Hubbell an entomologist by training, they contributed to our early understanding of the state's vegetation. Following field work across the state in the 1930s, they recognized the need to define and describe the major biotic areas of Oklahoma and in 1938 published a paper in the American Midland Naturalist. They defined 10 biotic districts and for each listed the principal plant associations present, with characteristic plant species and ecogeographic conditions.

Henry Ira (HI) Featherly-Our early knowledge of Oklahoma's grasses is due to the work of H.I. Featherly (Figure 27), an ecologist and taxonomist at Oklahoma Agricultural \& Mechanical College (later Oklahoma State University) from 1925 to 1958. Collaborating with the noted agrostologists A.S. Hitchcock and Agnes Chase at the U.S. National Herbarium, he documented the state's grass flora in papers published in the Proceedings of the Oklaboma Academy of Science $(1928,1930)$ and bulletins of the Oklahoma Agricultural Experiment Station $(1938,1946)$. Most notable is his 1946 Manual of the Grasses of Oklahoma which provided keys for identification, morphological descriptions, and illustrations for 301 grasses. He also documented the state's fern flora (Featherly and Russell 1939). In addition to his teaching and extension responsibilities, Featherly was instrumental in the establishment of the OSU Museum of Natural and Cultural History and was its first curator. As noted in our introduction, he was President of the Oklahoma Academy of Science in 1942 and gave the traditional presidential address at the luncheon that is the foundation of this essay.

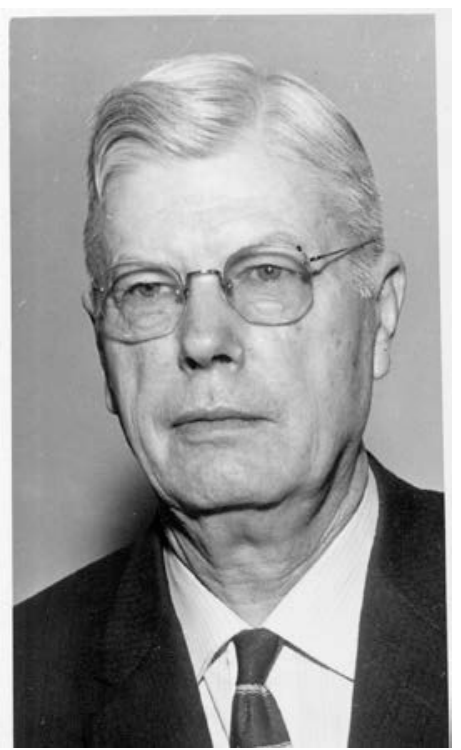

Figure 27 H.I. Featherly. Photo courtesy of the Special Collections and University Archives, Edmon Low Library, Oklahoma State University.

\section{Lester G. Duck and J.B. Fletcher-}

Although wildlife biologists in the Division of Wildlife Restoration and Research of the Oklahoma Game and Fish Commission, Duck and Fletcher $(1943,1945)$ produced a vegetation map of Oklahoma that it is the most widely recognized of all Oklahoma classifications of vegetation (Figure 28). It comprises 14 vegetation types called "game types" because the authors' intent was to describe habitats of game and fur-bearing animals in the state. The classification, descriptions, and map are the product of field mapping correlated with prior studies of vegetation, geology, soils, climate, and land use in relation to game animal populations (Tyrl et al. 2008). 


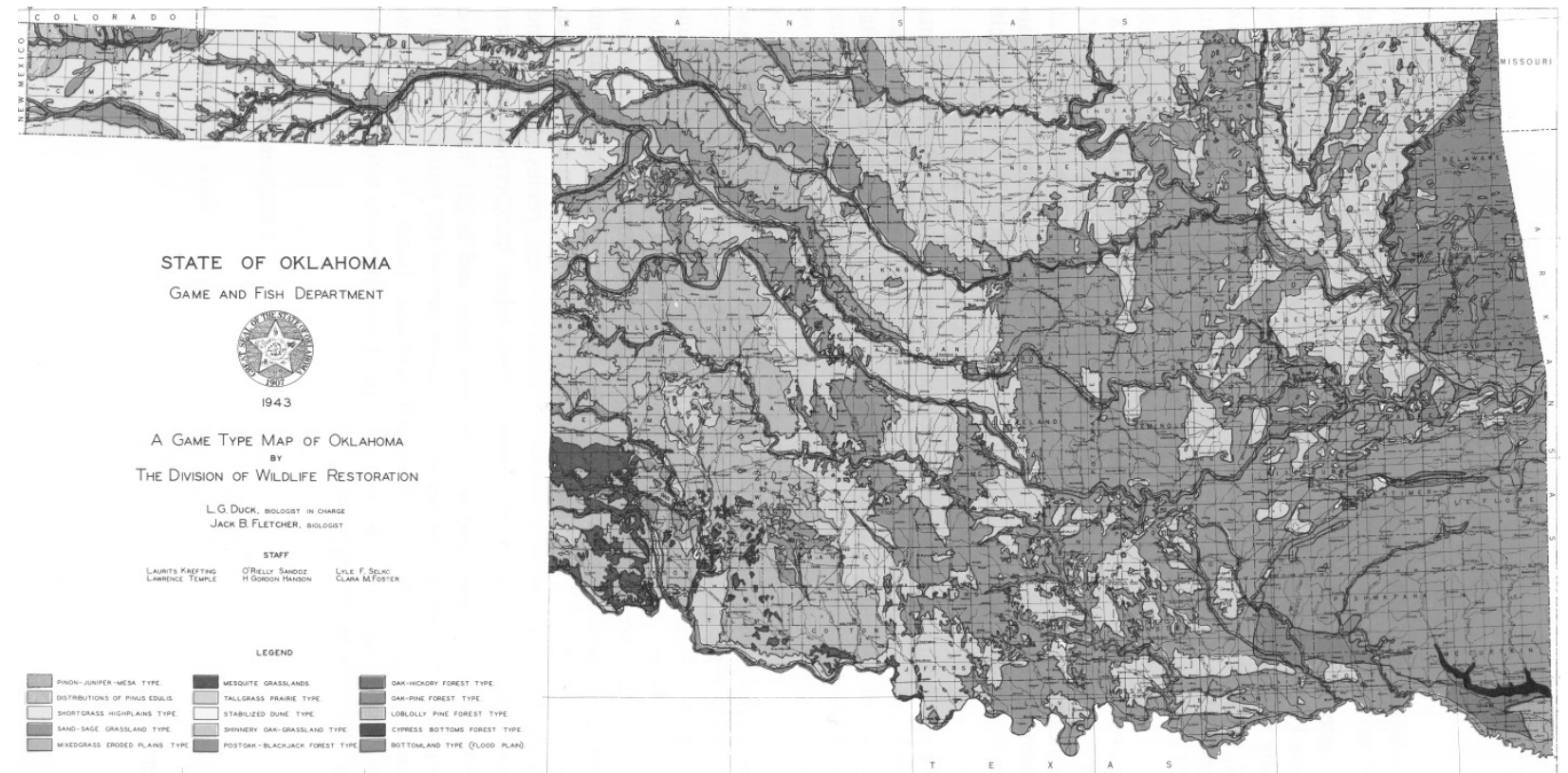

Figure 28 Duck \& Fletcher's A Vegetation (Game Type) Map of Oklahoma. Original reprinted by the Oklahoma Biological Survey with the permission of the Oklahoma Department of Wildlife Conservation.

Elbert Luther Little, Jr.-Although born in Fort Smith, Arkansas, Elbert Little (Figure 29) said that he was proud to be "an Okie from Muskogee," having grown up there (Anonymous 1993). After earning B.A. degrees in botany and zoology at the University of Oklahoma and M.S. and Ph.D. degrees at the University of Chicago, he worked for the Oklahoma Forest Commission in Broken Bow in southeastern Oklahoma and taught at Southwestern State College in Weatherford. Little eventually became a dendrologist with the U.S. Forest Service in Washington D.C. where he worked for 34 years, becoming Chief Dendrologist (Anonymous 1993).

Little's legacy to Oklahoma comprises, in part, numerous journal articles on the state's plants and interesting botanical areas (see Kelting and Penfound 1953; Milby 1977) and his numerous talks at the technical meetings the Oklahoma Academy of Science. The author of more than 23 books and 150 handbooks, bulletins, and technical papers, he is perhaps best known for his five editions of

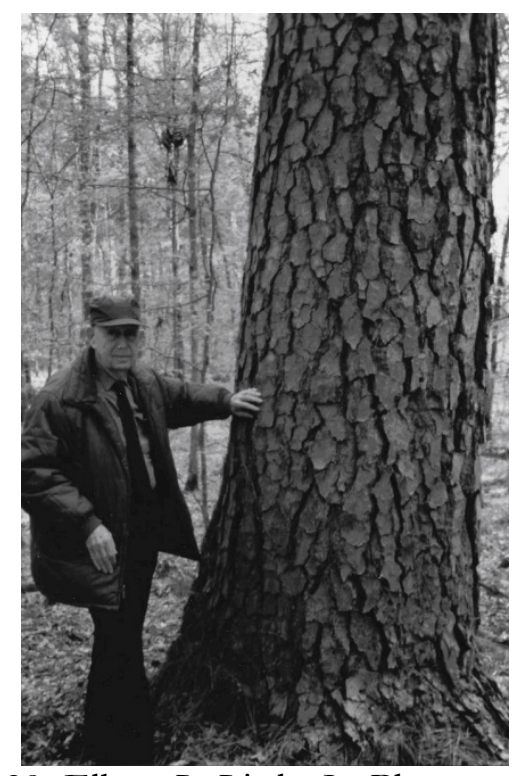

Figure 29 Elbert L. Little, Jr. Photo courtesy of Wayne Elisens, Bebb Herbarium, University of Oklahoma.

Forest Trees of Oklahoma (2000) in which he provided morphological descriptions, illustrations, and distributional maps for 164 species. Importantly, he also provided keys, based mainly on leaves and twigs, for their 
identification. At the national level, his twovolume Audubon Society Field Guide to North American Trees (1980a, 1980b) continues to be a popular reference.

While working for the Oklahoma Forest Commission in McCurtain County in 1930, he established a series of experimental plots. Returning to the plots in the 1980s, he was able to document changes in the forest and individual species during those 50 years. Figure 29 shows him standing beside one his marked trees-Pinus echinata (shortleaf pine).

Umaldy Theodore Waterfall-Most likely the person who has published more journal articles on the flora of Oklahoma than any other individual (see Kelting and Penfound 1953, Milby and Penfound 1965; Milby 1977), U.T. Waterfall (Figure 30) earned his B.S. at Oklahoma Agriculture \& Mechanical College in 1935 and M.S. (1942) and Ph.D. (1956) at the University of Oklahoma. In 1949, he joined the botany department at OAMC as curator of the herbarium.

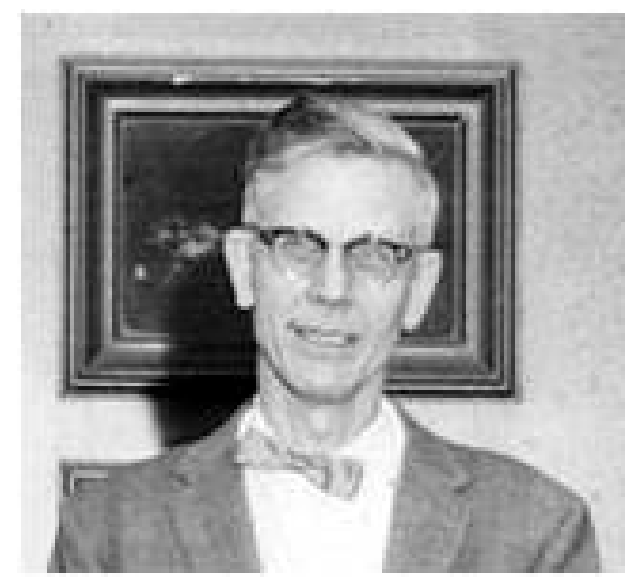

Figure 30 U.T. Waterfall. Photo courtesy of the Oklahoma State University Department of Botany.

Waterfall's interest in the flora of Oklahoma began in the 1930s, and by 1939 he had collected about 1,000 herbarium sheets. While completing his master's degree and teaching in the Oklahoma City public schools, he took field trips on weekends and school breaks to collect plants, eventually collecting throughout the state and traveling approximately 140,000 miles (Waterfall 1969). In 1940, he began reporting his discoveries in a series of papers published primarily in the journals Rhodora and the Proceedings of the Oklahoma Academy of Science. In 1952, he published $A$ Catalogue of the Flora of Oklahoma in which he listed 141 families, 741 genera, and 2,543 species, varieties, and forms.

Recognizing that there was an immediate need for a means of identifying these taxa, he immediately began writing taxonomic keys for their identification, making them available to students in his plant taxonomy classes at OSU. He personally typed and published four editions of Keys to the Flora of Oklahoma; the first edition appeared in 1960 and the fourth in 1969 (Figure 31). Later "editions" are only reprints of the fourth edition. Simultaneously with publication of these keys, he began to write diagnostic descriptions of each taxon. Unfortunately, this manuscript was not completed before his death in 1971. Waterfall's Keys was the principal means of identifying plants in Oklahoma for more than 30 years and was used by both state scientists and countless numbers of students. With permission of his heirs, it was combined with Key to the Vascular Plant Families of Oklahoma in the book Identification of Oklahoma Plants (Tyrl et al. 1994a, 1994b).

In addition to his work on the flora of Oklahoma, Waterfall was considered an expert on the genus Physalis (ground cherry) in the Solanaceae or nightshade family, the subject of his doctoral dissertation (Waterfall 1958). He collected extensively in Mexico, and his specimens are deposited in herbaria throughout the country. Waterfall also influenced the many students from botany, range science, agronomy, and forestry who took his plant taxonomy and agrostology classes. He was famous for his field trips on which he wore knee-high laced boots, drove county roads at high speeds - not worrying whether students in the following vehicles were keeping up_climbed fences, and 
botanized while rapidly striding across the prairies (Charles B. McDonald, personal communication).

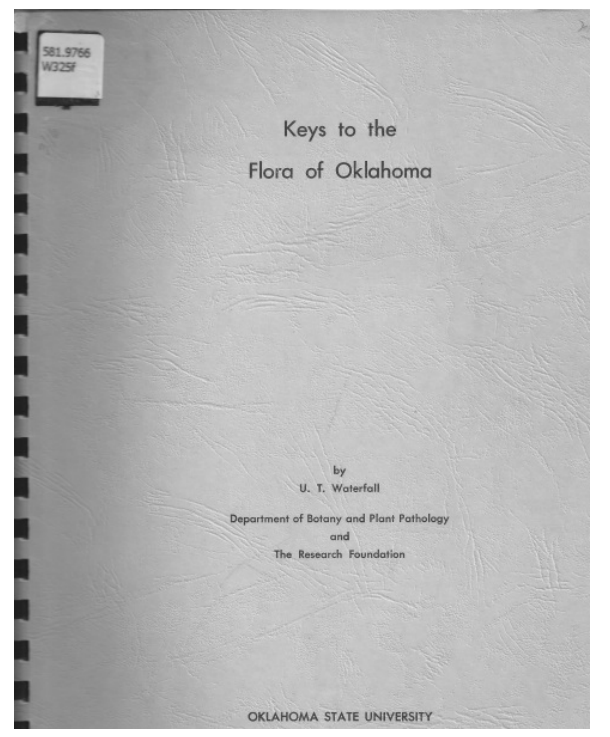

Figure 31 Well-worn cover of the first edition of Keys to the Flora of Oklahoma.

Charles Sparkman Wallis-Anyone examining specimens in the herbaria at the University of Oklahoma (OKL) and Oklahoma State University (OKLA) will undoubtedly encounter specimens bearing labels with the heading "Plants of Oklahoma Ozarks" and the collector name "C.S. Wallis." A high school teacher before WWII and an instructor at Conners State Agricultural College afterwards, Charles Wallis collected plants in the Ozark Plateau and Boston Mountains geomorphic provinces in northeastern Oklahoma. He completed a survey of the plants of Cherokee County, with the exception of the graminoids (grasses, sedges, and rushes) that was the basis for his master's thesis (Wallis 1953). Upon its completion, he realized the need to expand his survey to encompass the entire Oklahoma Ozarks. His initial collection of some 1,400 specimens expanded to about 7,000 and was described in a doctoral dissertation at Oklahoma State University, with U.T. Waterfall serving as his adviser (Wallis 1959). In his dissertation and two publications
(Waterfall and Wallis 1953, Wallis 1958), he reported 24 additions (species, varieties, and forms) to the state flora from the Oklahoma Ozarks. His specimens were deposited in the herbaria at Oklahoma State University and Southern Methodist University. In 2001, his personal collection of 7,000 specimens was donated by his son to the Bebb Herbarium at the University of Oklahoma.

Francis Hobart Means-Our knowledge of the flora of the northern portion of the Ouachita Mountains geomorphic provincebetween the Sans Bois and Kiamichi Mountains in Latimer, LeFlore, and Pushmataha Counties-begins with the work of Frank Means. While an instructor of botany and agronomy at Eastern Oklahoma State College in Wilburton, he began studying and collecting the area's flora. He eventually amassed a collection of some 4,200 specimens which served as the foundation for his doctoral dissertation completed under the direction of U.T. Waterfall at Oklahoma State University (Means 1969).

George J. Goodman-The author or coauthor of several books and multiple journal articles, including his numerous "Notes on Oklahoma Plants" published in the Proceedings of the Oklahoma Academy of Science, George Goodman (Figure 32) was curator of the herbarium at the University of Oklahoma from 1933 to 1936 and again from 1945 to 1975.

During his tenure, the herbarium more than doubled in size from approximately 80,000 specimens to 173,000 . In addition to actively collecting the state's flora, he named and described 36 taxa new to science (Rice and Cross 1990). In 1958, he published his Spring Flora of Central Oklahoma. As the title indicates, it was restricted in both area and season. Used in his plant taxonomy classes, it comprised keys for the identification of 680 species and infraspecific taxa. As a major professor for graduate students, he mentored several state taxonomists, including U.T. 
Waterfall, Doyle McCoy, and Constance Taylor, also described in this paper. Four plant taxa are named for him, and upon his retirement as curator, the university's Board of Regents named the foyer of the Robert Bebb Herbarium in his honor.

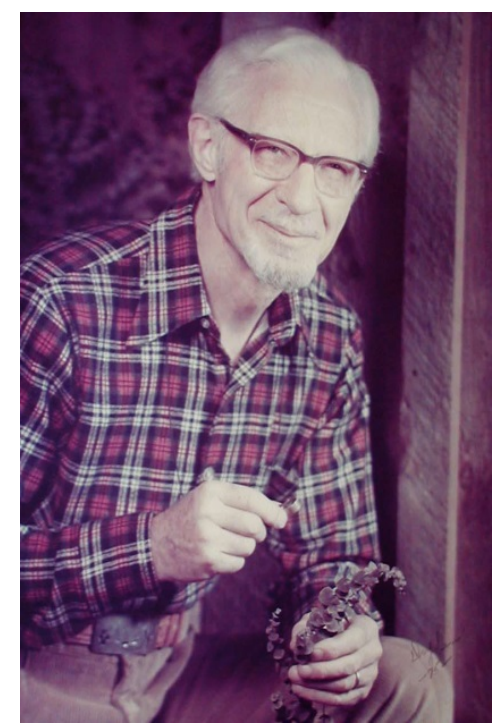

Figure 32 George J. Goodman. Photo courtesy of Wayne Elisen, Bebb Herbarium, University of Oklahoma.

Doyle Allen McCoy-The author of a popular series of field guides for Oklahoma plants used by many ONPS members, Doyle McCoy (Figure 33) was said to be "...obsessed with wildflowers when most people still called them weeds." (Bilger 1991). Beginning his academic career in a two-room schoolhouse near Chickasha, he subsequently earned his doctorate at Oklahoma State University in 1953 under the guidance of U.T. Waterfall. His dissertation topic was a survey of the plants of Pontotoc County.

His teaching career began at Ada High School, followed by positions at East Central University in Ada and Cameron University in Lawton. In his profile of McCoy, Burkhard Bilger (1991) describes him as being passionate about introducing students and the public to Oklahoma's native plants by leading field trips and giving lectures to garden clubs and civic groups-striving to get people to appreciate them and to even plant them. In 1968, he published A Study of Flowering Plants. Envisioned as an aid for his students who were beginning to identify plants, this book was essentially a mini, plant taxonomy textbook, comprising chapters covering phytographic terms, principles of classification, methods of collecting plants, use of taxonomic keys, a bibliography of manuals and floras, and "Keys to the Flora of a Region Extending From South-Central Oklahoma to West-Central Texas."

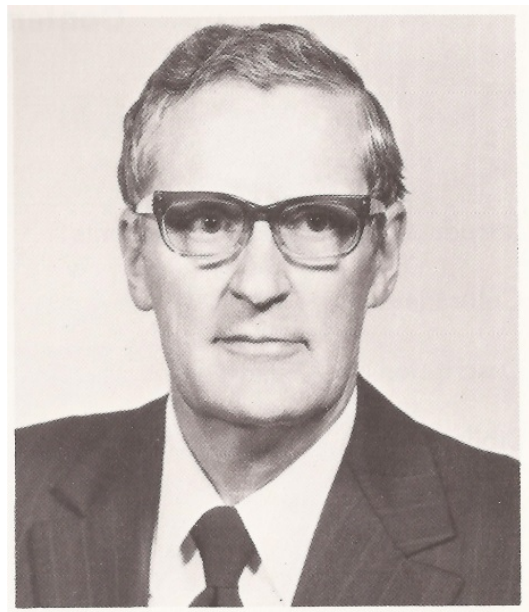

Figure 33 Doyle McCoy. Photo courtesy of D.A. McCoy.

Traveling about the state in a Datsun pickup truck and carrying a $35 \mathrm{~mm}$ camera, large trash bin, and a sheet of black velvet, Doyle photographed Oklahoma native plants "up close and personal." He assembled 300 of his photos and, accompanied by brief synopses of their morphological characters, geographical and ecological distribution, and flowering times, personally published Roadside Flowers of Oklahoma in 1976. "I took a chance and ordered 5,000 copies and went around to bookstores leaving them on consignment-no one really knew how they would go," Doyle said (Bilger 1991). This initial printing quickly did "go", and another 8,000 copies were ordered in 1978. A second volume appeared in 1978, followed by Roadside Wild Fruits of Oklahoma (1980), Roadside Trees and Shrubs of Oklahoma (1981), 
and Oklahoma Wildflowers (1987). This series of field guides represents the first photographic documentation of the state's flora and is especially valuable because of the diagnostic quality of photographs; they have been used by tens of thousands of individuals interested in Oklahoma's wildflowers.

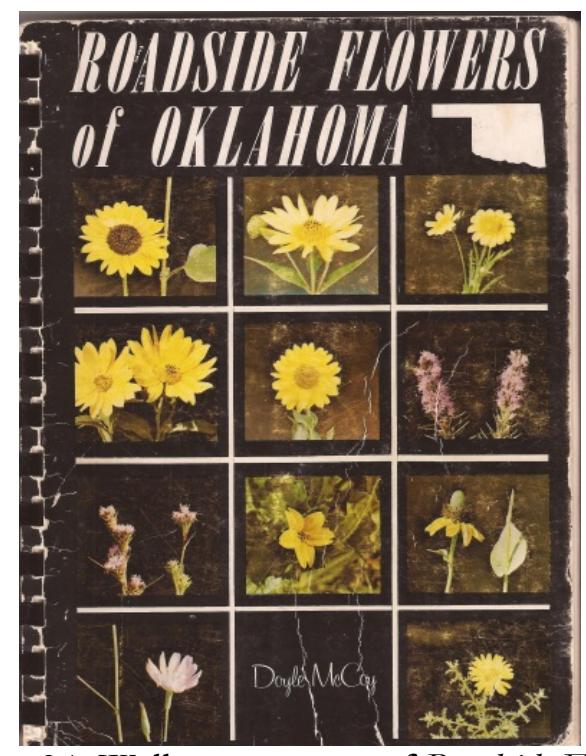

Figure 34 Well-worn cover of Roadside Flowers of Oklahoma so familiar to ONPS members.

Bilger (1991) recounted Doyle thought that perhaps his proudest accomplishment was the designation of Gaillardia pulchella (Indian blanket) as Oklahoma's state wildflower on March 20, 1986 (Figure 35). For several years, he had lobbied the legislature to substitute G. pulchella for Phoradendron secotinum (mistletoe) as our state flower. Finally, he convinced the legislature to once again call mistletoe Oklahoma's floral emblem and designate Indian blanket as Oklahoma's state wildflower. Interestingly, mistletoe originally had been designated the "Flora Emblem of the Territory" on February 11, 1893 and then "Floral Emblem of the State" in 1910 (Featherly 194-). Popular use had converted "state emblem" into "state flower."

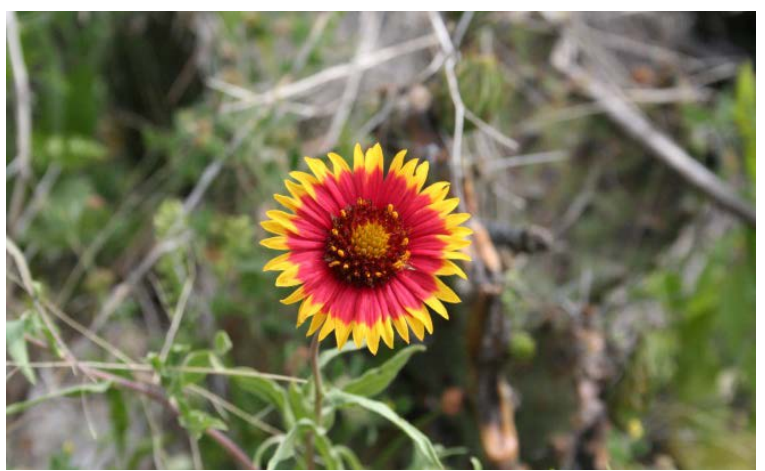

Figure 35 Gaillardia pulchella (Indian blanket), Oklahoma's state wildflower. Photo courtesy of Mike Nelson.

Torbert H. (T.H.) Milby-An individual who has contributed significantly to our knowledge of the flora and vegetation of Oklahoma, not by his field work but rather by his bibliographic endeavors, is T.H. Milby, retired Professor of Bibliography of University Libraries and Professor of Botany at the University of Oklahoma. As Rice and Cross (1990) noted, Milby joined the faculty in 1961 as a librarian, completed his Ph.D. in botany, developed an interest in enumerative botanical bibliography, and eventually published two papers (Milby and Penfound 1965; Milby 1977) and the book Oklahoma Botanical Literature (Johnson and Milby 1989). In addition, he also coauthored Proceedings of the Oklahoma Academy of Science: Index to Volumes 1-65, 1920-1985 (Milby and Hough 1988). The importance of these publications is that they provide immediate access to the wealth of information that has accumulated about the state's plants. He also coauthored Oklahoma Landscapes: A Century of Change (Milby et al. 2008) which pictorially documents, in a series of "before" and "after" photos with accompanying explanatory text, how some areas of the state have changed dramatically and other areas have remained essentially unchanged.

Paul F. Nighswonger-Our knowledge of the plants present in the northwestern corner of the body of the state is the result of extensive collecting by Paul Nighswonger, a 
longtime Professor of Biology at Northwestern Oklahoma State University (NWOSU) in Alva. His goal was to document the flora of Woods County and surrounding areas. In doing so, he amassed a collection of more than 1,900 specimens that he deposited in the university's herbarium. Like G.W. Stevens, his predecessor at NWOSU, he collected duplicate specimens and sent them to more than nine other herbaria throughout the United States. He was one of the founders of the Flora of Oklahoma project-an effort by state taxonomists to write and publish a modern floristic treatment for the state's vascular plants - and for several years served on its Editorial Committee. Many ONPS members will fondly remember him leading field trips in Woods County whenever the society's annual meetings or Wildflower Workshops were held in Alva.

Forrest Lee Johnson-Recognized by his coworkers to be perhaps the most knowledgeable person about the bottomland forests of Oklahoma, Forrest Johnson was a research biologist for the Oklahoma Biological Survey from 1975 until his death in 1999. After receiving his B.S. degree in chemical engineering and pursuing careers in engineering, farming, and high school teaching, he earned his M.S. and Ph.D. in plant ecology at the University of Oklahoma. He authored or coauthored numerous journal articles on the ecology of the state's forest communities and various tree species. His writing also included two notable books, Oklahoma Botanical Literature (Johnson and Milby 1989) and Oklahoma Landscapes: $A$ Century of Change (Milby et al. 2008), and the website Catalog of the Woody Plants of Oklahoma: Descriptions and Range Maps (Johnson and Hoagland 1999).

In addition to his ecological research and writing, Forrest was an untiring plant collector of the state's flora, often being in the field almost the entire growing season. He also was a major participant in the U.S. Army Corps of Engineers Construction Engineering Research
Laboratory (CERL) plant surveys of military installations across the country and in practically all biomes (J.R. Estes, personal communication). His collections of voucher specimens contributed substantially to the Bebb Herbarium's holdings.

Lawrence (Larry) K. Magrath-Following completion of his doctoral dissertation on the native orchids of the prairies and plains of North America, Larry Magrath (Figures 36, 37) began a 35-year career teaching at the University of Science and Arts of Oklahoma in Chickasha. As curator of the university's herbarium, he collected thousands of plants throughout the state and increased its size to an estimated 22,000 sheets. He was well known for his keen eye in spotting "different" appearing plants and the discovery of species previously unknown to occur in the state. He was especially diligent in collecting duplicate specimens which were subsequently distributed to herbaria throughout the country.

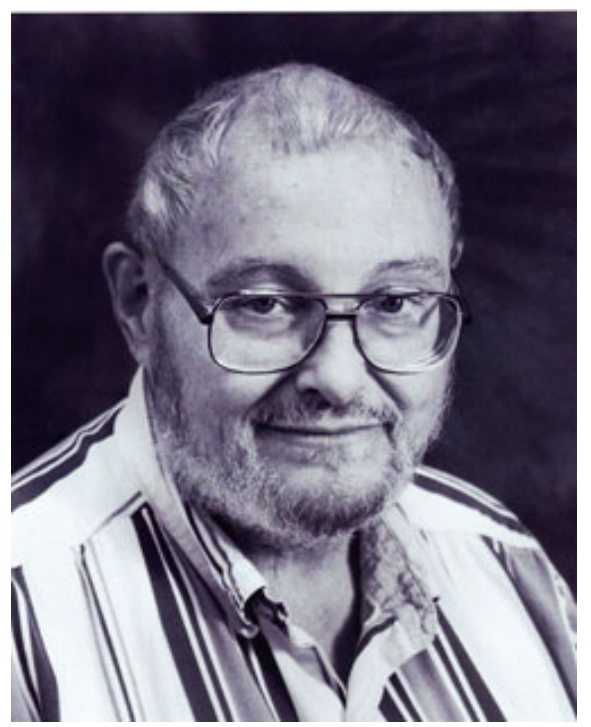

Figure 36 Lawrence K. (Larry) Magrath. Photo courtesy of Ingrid Shafer.

An expert on orchids, Larry wrote numerous journal articles on their geographic distribution, published Native Orchids of Kansas (1971), coauthored the family treatment of the 
Orchidaceae in the Flora of North America (Romero-González et al. 2002), authored or coauthored six generic treatments in the same work, and in the 2001 premiere issue of this journal published his Native Orchids of Oklahoma, which comprised keys, photographs, descriptions, and distribution maps. He was one of the founders of the Flora of Oklahoma project - an effort by state taxonomists to write and publish a modern floristic treatment for the state's vascular plants. In addition to contributing and editing the treatments of different families, he took primary responsibility for the Orchidaceae (18 genera and 33 species) and served as the project's secretary and treasurer for many years.

Larry contributed to the public's awareness of Oklahoma's wildflowers by his enthusiastic participation in ONPS programs and field trips, the Wildflower Workshops series, and the Oklahoma Junior Academy of Science. He is honored by the binomial Schoenoplectiella $\times$ magrathii, Magrath's bulrush, the name of an interspecific hybrid that he found in the midst of a mixed population of S. ballii and S. saximontana in the Wichita Mountains in Comanche County (Smith and McKenzie 2013).

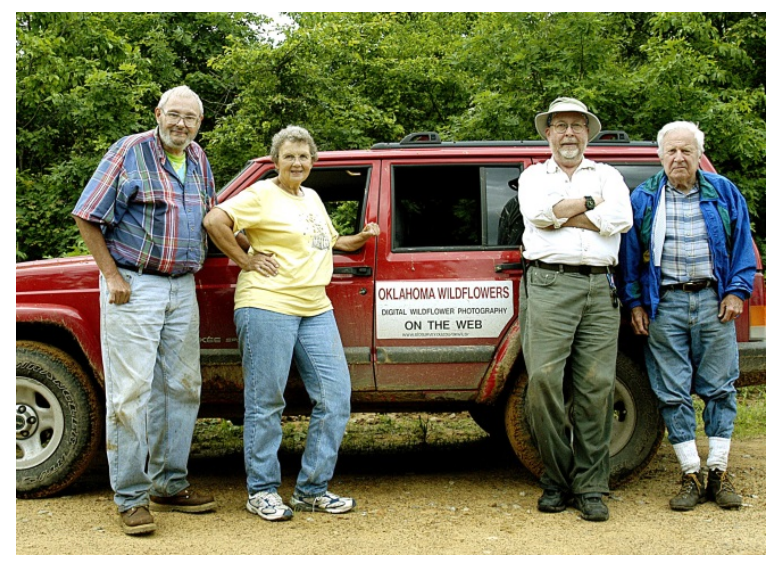

Figure 37 Larry Magrath, Patricia Folley, Charles Lewallen, and Jim Norman on a field trip to Round Mountain in LeFlore County in 2007. Photo courtesy of Patricia Folley.
A little known fact to most people, Larry was artistic, using plants as themes in his three-dimensional visual art and his poetry. This poem, "Lady's Slipper," is among many written by Larry and published in poetry journals.

\section{Lady's Slipper}

In a forest cathedral,

Made by no man's hand, fashioned of trees, Some great and some small,

I walked in awe upon the softest of carpets, Woven upon no loom in softly filtered pale green light, Shot through with rays of gold and purest white While round me sounded the sweetest, Most innocent bymns of all, Sung by God's small feathered creatures. Then I saw it standing tall, Swaying slightly in the gentle breeze, Stem and leaves of emerald green With a golden slipper at its tip, The golden lip rimmed round with red, A miniature cathedral of light With a staminode for a pulpit. God's hands have touched all, But with this perfect creation His hands must have lingered long. How else account for such beauty As the lady's slippers One and all?

\section{R. John and Constance (Connie) E.S.}

Taylor-The intertwined professional careers of John and Connie Taylor (Figure 38) have certainly enhanced our knowledge of the flora of Oklahoma. After meeting in the Bebb Herbarium and subsequently marrying, both earned their doctorates in the Department of Botany and Microbiology at the University of Oklahoma and became professors of biology at Southeastern Oklahoma State University (Anonymous 1994). In addition to individually publishing numerous journal articles on the taxonomy and distribution of Oklahoma species (see citations in Johnson and Milby 1989), they jointly published An Annotated List of Rare or Infrequently Collected $V$ ascular Plants 
that Grow in Oklahoma (1978) and three editions of An Annotated List of Ferns, Fern Allies, Gymnosperms and Flowering Plants of Oklahoma (1989, 1991, 1994). The latter book (Figure 39) provides a list of the scientific names of the state's species plus their authors, common names, synonyms, nativity, longevity, habit, and general geographic distribution. Together, John and Connie conducted an active collecting program, and their accessions number in the tens of thousands, with duplicate specimens deposited both in state and national herbaria.

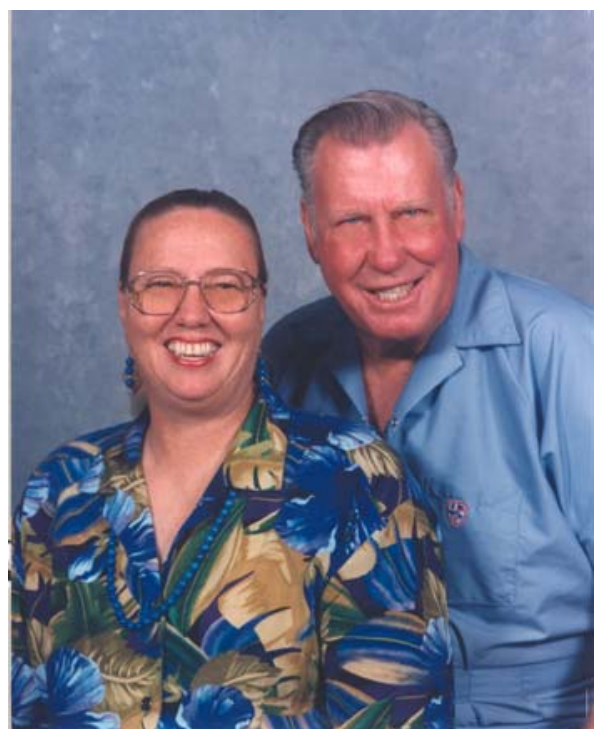

Figure 38 John and Constance (Connie) Taylor. Photo courtesy of Wayne Elisen, Bebb Herbarium, University of Oklahoma.

John was a dedicated field botanist and established the SEOSU Herbarium in 1969 using his private collection and those of Connie, Don Hazell, and James Lester; in 1993 it comprised more than 80,000 sheets (Anonymous 1994). In addition to his plant collecting in Oklahoma-with the goal of recollecting every species known to grow in the state- he worked in Alaska, the Rocky Mountain states, western Canada, Mexico, and Costa Rica. Named in his honor are Elaphoglossum tayloranum (Taylor's tongue-fern) and Castilleja tayloriorum (Taylor's Indian paintbrush), two Costa Rican species new to science collected by Connie and him in 1972 (Anonymous 1994).

In addition to collecting plants with John, Connie independently conducted systematic studies of the composite genera Solidago (goldenrod) and Euthamia (goldentop). In doing so, she described (Taylor and Taylor 1983) Solidago altiplanities (high plains goldenrod), an Oklahoma species new to science. Her extensive knowledge of Oklahoma members of the Asteraceae, or sunflower family, was embodied in her Keys to the Asteraceae of Oklahoma published in 1997, which subsequently was incorporated into the Illustrated Flora of North Central Texas (Taylor 1999).

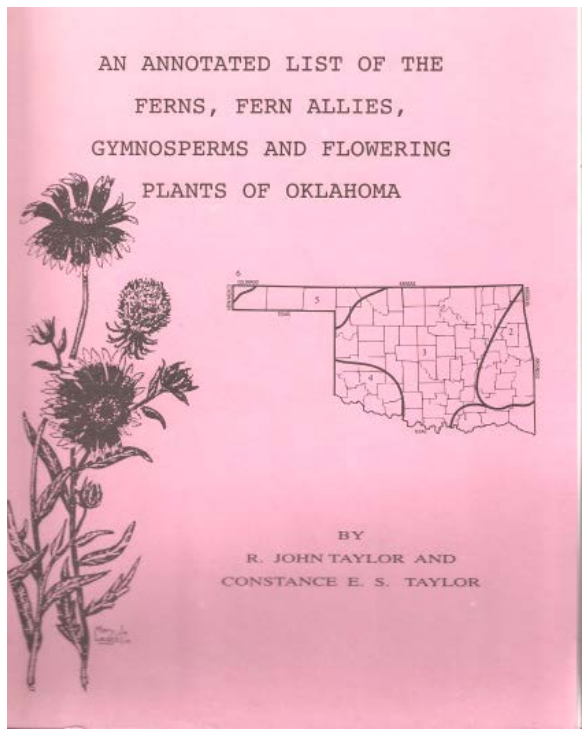

Figure 39 Third Edition of An Annotated List of Ferns, Fern Allies, Gymnosperms and Flowering Plants of Oklahoma used by many ONPS members.

Connie is also one of the founders of the Flora of Oklahoma project-an effort by state taxonomists to write and publish a modern floristic treatment for the state's vascular plants. In addition to taking primary responsibility for the Asteraceae, she has drafted and edited keys and descriptions for the genera of many other families.

Her unstinting service in various state organizations has contributed to public 
awareness of Oklahoma's biodiversity. In addition to repeatedly being a field trip leader on ONPS and Wildflower Workshop outings, she has served as president of ONPS, the Oklahoma Ornithological Society, and the Oklahoma Academy of Science. In 1998, she received the ONPS's Anne W. Long Award for Promotion of Native Plants in Oklahoma in recognition of her contributions to the society and state.

Paul Buck - The individual perhaps best known for botanizing in Oklahoma-whether leading ONPS field trips, conducting ecological research, or collecting the state's flora-is Paul Buck (Figure 40), Professor of Botany at the University of Tulsa (TU) for many years. Following service in the Navy at the end of the Second World War and duty as a policeman in Tulsa, he earned his bachelor's and master's degrees at the University of Tulsa. His major was botany and his minor was zoology. His master's thesis dealt with the ecology of a tallgrass prairie in northeastern Oklahoma. Completed in 1962, his doctoral program was at the University of Oklahoma where he again opted for botany with a minor in zoology. His dissertation, a study of the relationships of woody vegetation to geology and soil in the Wichita Mountains Wildlife Refuge, was subsequently published in the journal Ecology. After completing his doctorate, Paul returned to his alma mater, the University of Tulsa, as an Assistant Professor of Botany and taught a variety of courses. In addition, he taught summer field courses for many years at The Rocky Mountain Biological Laboratory in Gothic, Colorado, one of the most famous field stations in North America.

Paul was a botanist with diverse interests. He published numerous scientific articles on a wide range of topics - ecology of woody vegetation, interspecific hybridization, and plant succession. Notable is his collaboration with TU colleague Estelle Levetin resulting in a series of journal articles on allergenic plants in Oklahoma. His research and writings contributed significantly to our understanding

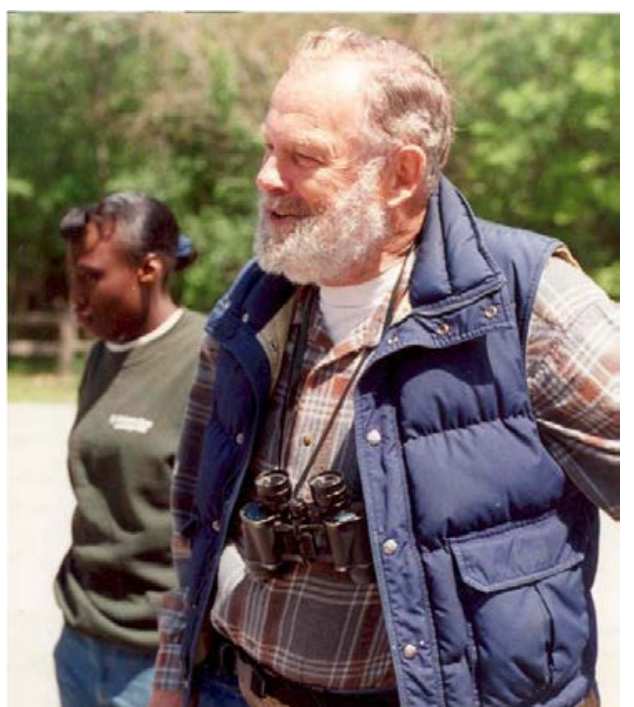

Figure 40 Paul Buck. Photo courtesy of Lou Ann Buck.

of the flora and vegetation of Oklahoma. His two editions $(1983,1991)$ of Distribution and Identification of Woody Plants of Oklahoma in the Winter Condition have been used by countless individuals becoming acquainted with the woody flora of the state (Figure 41).

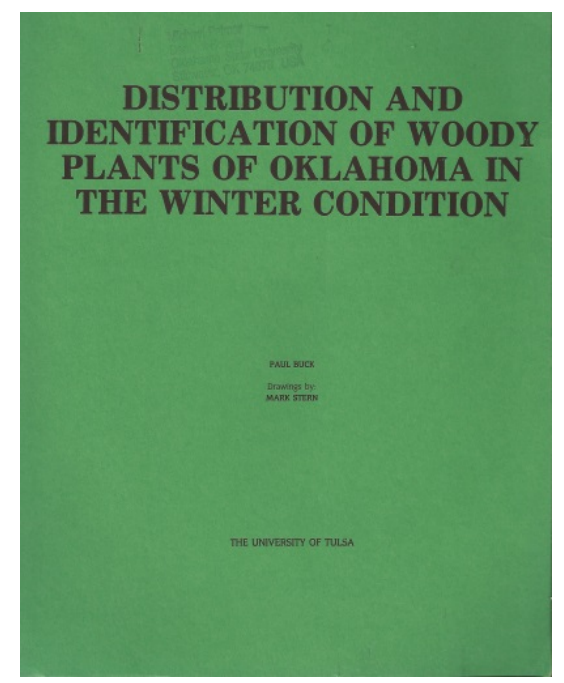

Figure 41 Distribution and Identification of Woody Plants of Oklahoma in the Winter Condition used by state scientists, students, and members of ONPS.

Paul was instrumental in the formation of a consortium of state taxonomists and ecologists to write a modern manual for 
identification of the state's vascular flora-The Flora of Oklahoma project. In addition to writing, editing, and proofing the treatments of families and genera, especially the woody taxa, he took primary responsibility for the glossary and served as the project's treasurer for many years. In addition to his traditional writing as a scientist, Paul also was a disseminator of knowledge and made botanical phenomena meaningful to the general public via his quarterly column titled "Botany Bay" in the Gaillardia, the newsletter of the Oklahoma Native Plant Society, an organization that he played an instrumental role in forming. As an active member, he led innumerable field trips for the society and repeatedly served as a board member and the chair of various ad hoc committees. He also was involved in the creation of Color Oklahoma, an organization within ONPS dedicated to beautifying state highways with wildflowers.

Paul had a profound influence on many individuals. As a teacher, scientist, and field trip leader, he gave countless students, colleagues, and members of the public an appreciation of Oklahoma's plants and vegetation. His impact is reflected in the numerous awards and honors bestowed upon him: the ONPS Anne W. Long Award for Promotion of Native Plants, the ONPS Service Award, the Oklahoma Academy of Science (OAS) Service Award, and the OAS Teaching Award. On November 3, 2006, the academy paid tribute once again by sponsoring The Natural History of Oklahoma: $A$ Symposium Honoring Dr. Paul Buck and bestowing upon him a Lifetime Achievement Award for his contributions to the advancement of science in the state (Tyrl 2006).

Patricia (Pat) Folley-When asked about her contributions to our knowledge about the flora of Oklahoma, Patricia Folley (Figures 37, 42) modestly replied, "I haven't done very much, but I have had fun." Those of us who have worked with her and/or used her wildflower guide, know that her statement is certainly not accurate.

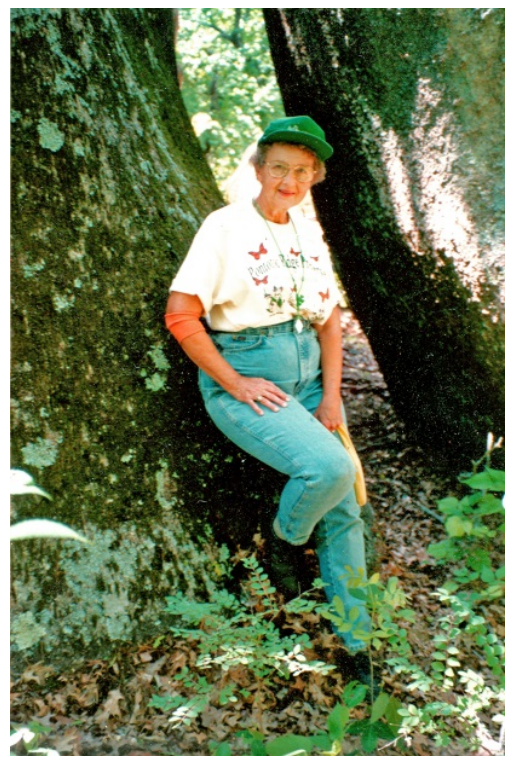

Figure 42 Patricia Folley in the field in 1997.

Pat traces her interest in Oklahoma's wildflowers back to her childhood. When she was 10 years old, her family moved to a home on the outskirts of Oklahoma City where she first began looking at the wildflowers and trying to identify them. Marriage, children, and a career as a logistics management specialist for the U.S. Air Force kept her busy until the 1980s. She then enrolled in a short course on plant identification taught by Jim Estes at the University of Oklahoma, who subsequently offered her the opportunity to work in the Bebb Herbarium when she retired. She gladly accepted the offer and learned to identify plants using taxonomic keys while working on the herbarium's backlog of unidentified specimens. She gratefully acknowledges the assistance of Estes, George Goodman, and Staria Vanderpool who helped her until she was able to work independently. Upon retirement, she also began volunteering for The Nature Conservancy to conduct surveys and to collect and identify plants throughout the state, from Beaver's Bend in the extreme southeast to Black Mesa at the end of the Panhandle. She has collected more than 2,100 
specimens and many duplicates that have been distributed to herbaria throughout the country.

In 1992, Pat was invited to join the Flora of Oklahoma Project as a member of the editorial committee and a trustee. She undertook the task of mastering the more than 90 species of Carex in the state- - a task almost all taxonomists shy away from-as well as the other 14 genera and 95 species of the Cyperaceae in Oklahoma. While doing field work and writing keys and descriptions for the flora project, she was also working hard to make ONPS a success. She served as a board member, chapter chair, president (twice), editor of the Gaillardia (the society's newsletter), a columnist writing the Botanist's Corner, and a field trip leader.

In 2011, Pat authored The Guide to Oklahoma Wildflowers (Figure 43), a compilation of wildflower photos which is most certainly a worthy successor to Doyle McCoy's series. Perhaps she was motivated by her encounter with a city librarian who dismissed her request for a picture book to help her identify the wildflowers when she was young and investigating wildflowers on the edge of Oklahoma City. She began drawing pictures of her plants and then began photographing them long before she began formal collecting. She has since amassed a large collection of $35 \mathrm{~mm}$ slides that have been the basis of popular slide shows at schools and meetings of ONPS, garden clubs, and civic groups.

Pat's contributions have been formally recognized as she has received both the ONPS Anne W. Long Award for Promotion of Native Plants and the ONPS Service Award for outstanding contributions, as well as the Conservation Award from the Oklahoma chapter of The Nature Conservancy. Although she sometimes describes herself as an "amateur botanist" because of her lack of formal training in plant taxonomy, Pat is most definitely not an amateur.

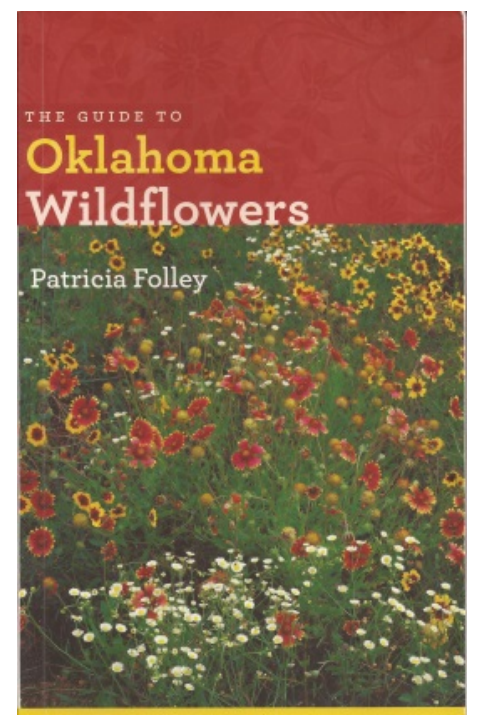

Figure 43 The Guide to Oklahoma Wildflowers.

Bruce W. Hoagland and Amy K.

Buthod-As research scientists for the Oklahoma Biological Survey, Bruce Hoagland and Amy Buthod have conducted numerous surveys of various areas throughout the state and in doing so have collected more than 26,000 herbarium specimens between them. The results of their work-more than 30 papers - have appeared in this journal, the Proceedings of the Oklahoma Academy of Science, and a variety of regional and national journals. While conducting their field work, they have discovered, independently or jointly, 15 species previously unknown to occur in the state.

Bruce has a joint appointment between the Survey and the Department of Geography and Environmental Sustainability at the University of Oklahoma. Both a geographer and a plant ecologist, he authored (2000) a classification of the state's vegetation-the first since that of Duck and Fletcher (1943) using the framework developed by the Federal Geographic Data Committee in 1997. In addition to being a botanical specialist for the Survey and collections manager of the Bebb Herbarium, Amy is also a heritage botanist for the Oklahoma Natural Heritage Inventory and in charge of tracking and monitoring populations of the state's rare plant species. 
Collaborating with Ian Butler, Wayne Elisens, and Ron Tyrl; Bruce and Amy were the recipients of a National Science Foundation grant for the development of the Oklahoma Vascular Plants Database (OVPD) and website

(http://www.oklahomaplantdatabase.org/). Derived from Bruce and Amy's previous database work on the Atlas of the Flora of Oklahoma project, the OVPD provides convenient and rapid access to the information associated with collections of
Oklahoma plants deposited in all_state herbaria. Label information is recorded, as well as taxonomic annotations, thus allowing users to extract and sort information, such as species distributions, localities, habitats, and phenology, as well as generating county floras and lists of specimens collected by various individuals (Figure 44). Prior to the development of the database, this information had to be laboriously extracted by examination of specimens in each of the state's herbaria.

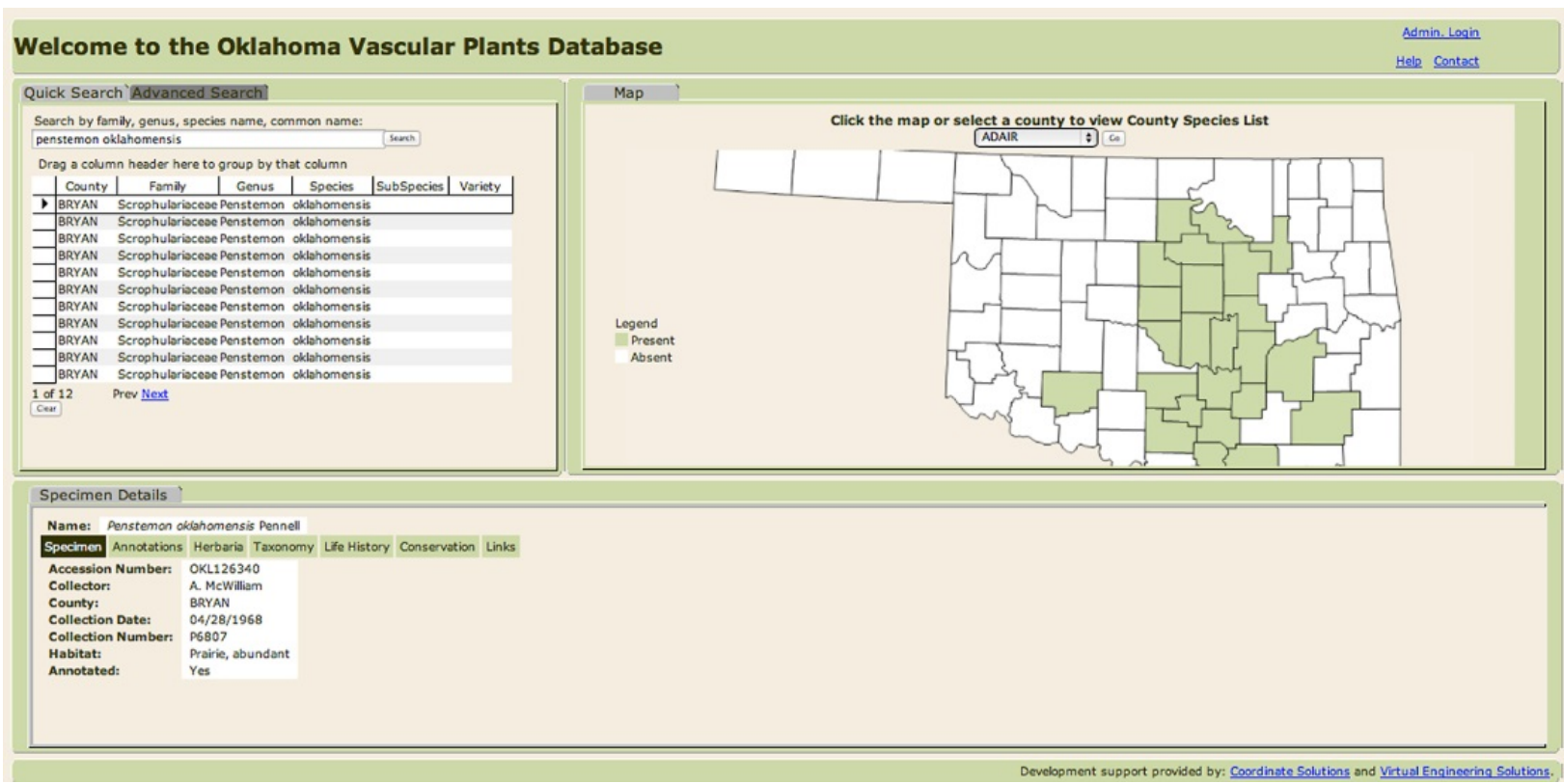

Figure 44 Opening screens of the Oklahoma Vascular Plants Database.

\section{The Flora of Oklahoma Editorial}

Committee-As has been mentioned in several of the preceding synopses, botanists from throughout the state undertook in 1983 the writing of a modern floristic treatment for Oklahoma's vascular plants. For two decades, the last edition of U.T. Waterfall's Keys to the Flora of Oklahoma (1969) had been the primary taxonomic reference for identifying plants. During this time, numerous taxonomic revisions of families and genera had been published, and many nomenclatural changes had been made. Additional native taxa had been discovered, and taxa introduced to the state had naturalized (Tyrl et al. 2010). Thus, the need for an up-to-date treatment was recognized.

Initial steps included the establishment of an editorial board, formation of a non-profit corporation, development of an editorial format, production of a computerized database for family descriptions, solicitation of contributors, and in 1992 initiation of research and writing. In order to provide students and other individuals with taxonomic keys and descriptions as quickly as possible, the editorial board employed essentially the same approach as that of Waterfall and 
decided to complete sequentially a key to families, descriptions of families, keys to the genera of each family, keys to the species of each genus, and finally the descriptions of genera and their species. Keys to the V ascular Plant Families of Oklahoma appeared in 1994 (Tyrl et al. 1994a). It was originally intended to be used in conjunction with Waterfall's Keys for genera and species until the new manual could be completed. Unexpectedly, the last copies of Waterfall's book were sold, and his heirs chose not to print it again. They kindly granted Flora Oklahoma, Inc. permission to print and combine it into a single work with the Keys to Families, so that students and other users could continue to have a readily available means of identifying Oklahoma plants. In order to recognize the monumental effort of Waterfall, the editorial board decided to leave his treatment intact and published Identification of Oklahoma Plants (Tyrl et al. 1994b) as a book with two independent parts.

In the late 1990s, revised versions of Identification were printed each semester in response to feedback from students and other users as to their efficacy. Finally in 2001, keys to all genera and species were completed by the editorial committee, and the first iteration of Keys and Descriptions for the V ascular Plants of Oklahoma appeared (Figure 45; Tyrl et al. 2010). At present, genera and species descriptions are being written. As before, previously written keys are revised, and the taxonomy and nomenclature of various families and genera are revised as needed.

Because of teaching responsibilities and other professional commitments, work on the project is slow but steady. The editorial committee (Figures 46-49) meets one Saturday a month in the Bebb Herbarium at the University of Oklahoma for a day-long session of examining specimens, writing, and editing. Committee members prepare drafts of keys and descriptions to be reviewed by the committee as a whole. In the fall of 1983, the committee comprised 10 botanists. At present, it comprises 12 ONPS members quite familiar to many of you: Susan Barber,

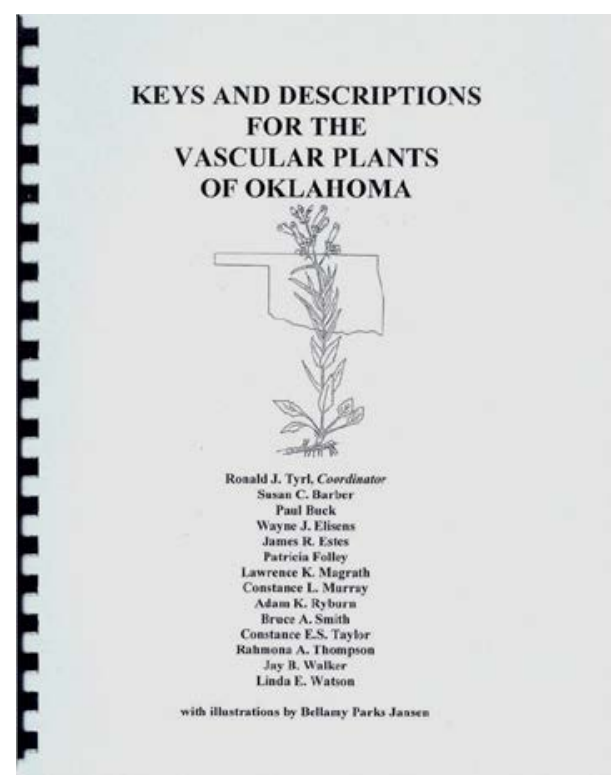

Figure 45 August 2010 revision of Keys and Descriptions for the V ascular Plants of Oklahoma.

Wayne Elisens, Jim Estes, Pat Folley, Connie Murray, Adam Ryburn, Bruce Smith, Connie Taylor, Rahmona Thompson, Ron Tyrl, Jay Walker, and Linda Watson. Founding members Paul Buck and Larry Magrath were major contributors to the project until their deaths (see Figures 46-49).

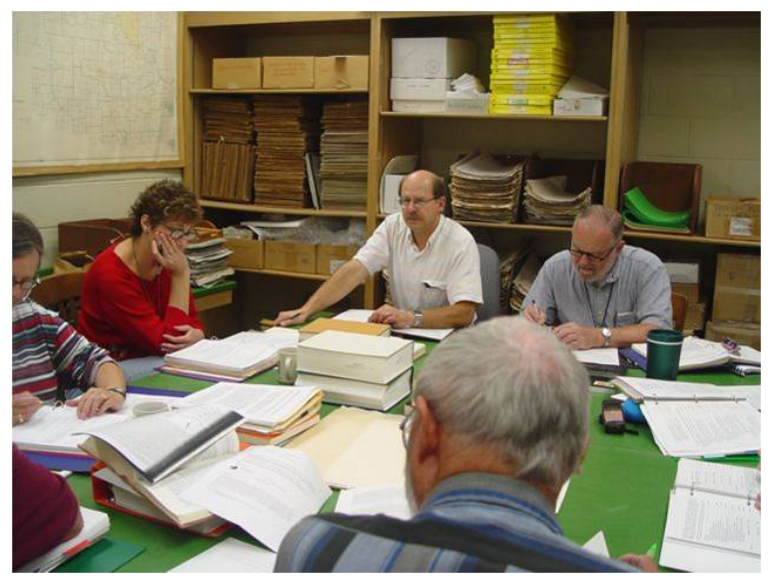

Figure 46 (from left) Susan Barber, Rahmona Thompson, Wayne Elisens, Larry Magrath, and Paul Buck, members of the editorial committee, at work on a Saturday morning in the Bebb Herbarium. 


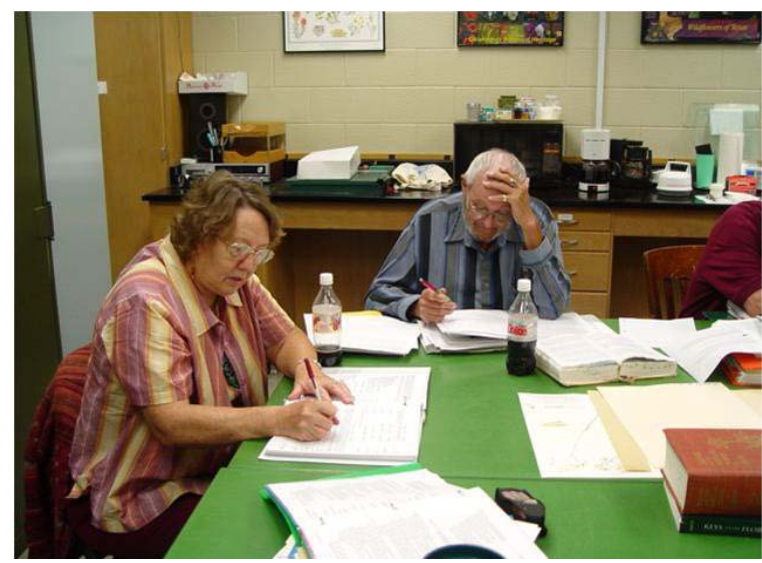

Figure 47 Connie Taylor and Larry Magrath, members of the editorial committee, at work on a Saturday morning in the Bebb Herbarium.

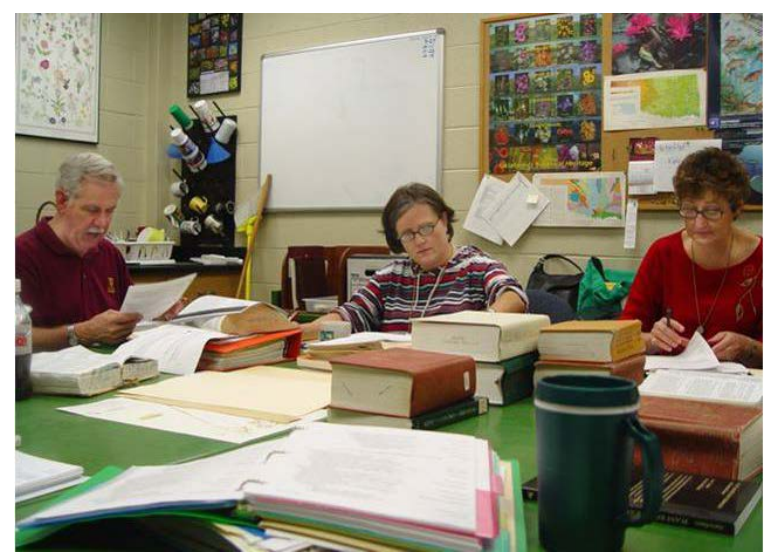

Figure 48 (from left) Ron Tyrl, Susan Barber, and Rahmona Thompson, members of the editorial committee, at work on a Saturday morning in the Bebb Herbarium.

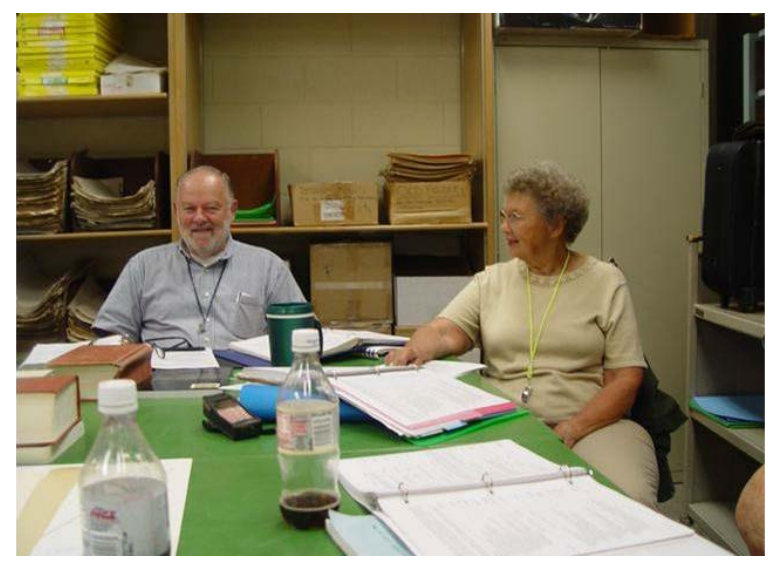

Figure 49 Paul Buck and Pat Folley, members of the editorial committee, at work on a Saturday afternoon in the Bebb Herbarium.
Other Collectors in Our Cavalcade-As the preceding review of field botanists in Oklahoma has hopefully made obvious, our knowledge of the state's flora and vegetation is the result of endeavors by many individuals with quite diverse backgrounds. Some individuals have conducted floristic surveys of counties, geological areas, or botanically interesting areas; others have surveyed particular plant groups. We acknowledge that our list of contributors is by no means complete; many others have contributed as well. Bibliographies on the vegetation of Oklahoma (Kelting and Penfound 1953; Milby and Penfound 1965; Milby 1977; Johnson and Milby 1989) cite individuals and their work only through 1975. Unfortunately, a more recent compilation of publications has not been made. Given the ecogeographic and floristic diversity that characterizes our state, our cavalcade of field botanists in Oklahoma will undoubtedly continue.

\section{LITERATURE CITED}

Anonymous. 1993. OAS Award of Merit 1992. Elbert Luther Little, Jr. Oklahoma Scientist of the Year. Proceedings of the Oklahoma Academy of Science 73:81-82. Anonymous. 1994. OAS Award of Merit 1993. R. John and Connie Taylor Oklahoma Scientists of the Year. Proceedings of the Oklaboma Academy of Science 74:57-58.

Benson, M.L. 1968. Edwin James Scientist, Linguist, Humanitarian [dissertation]. Boulder (CO): University of Colorado. Bilger, B. 1991. Wildflower redux. Oklahoma Today 41:8-18.

Blair, W.F. and T.H. Hubbell. 1938. The biotic districts of Oklahoma. American Midland Naturalist 20:425-454.

Bogue, E.E. 1899. Weeds of Oklahoma.

Oklahoma Agriculture Experiment Station Bulletin No. 41. Stillwater (OK).

Bogue, E.E. 1900a. Native Oklahoma Plants.

Oklahoma Agriculture Experiment Station 
Bulletin No. 45 (Popular Edition). Stillwater (OK).

Bogue, E.E. 1900b. An Annotated Catalog of the Ferns and Flowering Plants of Oklahoma. Oklahoma Agriculture Experiment Station Bulletin No. 45. Stillwate (OK).

Bolton, H.G. 1916. Spanish Exploration in the Southwest 1542-1706. New York: Charles Scribner's Sons.

Branson, C.C. 1959. Historical research in geology. Chronicles of Oklahoma 37:238239.

Bruner, W.E. 1931. The vegetation of Oklahoma. Ecological Monographs 1:99-188.

Butler, G.D. 1878. A list of some of the most interesting species of plants collected in the Indian Territory. Botanical Gazette 3:65-68, 74-78.

Buchanan, J.S. and E.E. Dale. 1939. A History of Oklahoma. New York: Row \& Peterson.

Buck, P. 1991. Distribution and Identification of Woody Plants of Oklahoma in the Winter Condition. 2nd Edition. Norman (OK): Oklahoma Academy of Science.

Carleton, M.A. 1892. Observations on the native plants of Oklahoma Territory and adjacent districts. Contributions from the U.S. National Herbarium 1:220-232.

Carpenter C.C. 2000. Early Oklahoma naturalists and collectors. Occasional Papers of the Sam Noble Oklaboma Museum of Natural History 6:1-46.

Curtis, N.E. Jr. and W.E. Ham. 1972. Geomorphic provinces of Oklahoma. p. 3. In: K.S. Johnson, C.C. Branson, N.E. Curtis Jr., W.E. Ham, W.E. Harrison, M.V. Marcher, and J.F. Roberts. 1979. Geology and Earth Resources of Oklahoma. An Atlas of Maps and Cross Sections. Oklahoma Geological Survey Education Publication Number 1. Norman (OK).

Dale, E.E. and J.L. Rader. 1930. Readings in Oklahoma History. Evanston (IL): Row Publishing.

de Oñate, D.J. 1601. Relacion Verdadera de los sucesos de la entrada que hizo el governado D.
Juan de Onate en las problaciones de Nueva Megico hacia el Norte. Reprinted in Bolton, H.G. 1916. Spanish Exploration in the Southwest 1542-1706. New York: Charles Scribner's Sons. pp 250-267.

Duck, L.G. and J.B. Fletcher. 1943. A game type map of Oklahoma.In: A Survey of the Game and Fur-bearing Animals of Oklahoma. Oklahoma City (OK): Oklahoma Department of Wildlife Conservation.

Duck, L.G. and J.B. Fletcher. 1945. The game types of Oklahoma: Introduction. In: A Survey of the Game and Fur-bearing Animals of Oklahoma. State Bulletin No. 3. Oklahoma City (OK): Oklahoma Department of Wildlife Conservation.

Engelmann, G. and G.D. Butler. 1878. The species of Isoëtes of the Indian Territory. Botanical Gazette 3:1-2.

Everett, D. 2009. Abert Expedition. pp. 1-2. In: D. Everett (editor). Encyclopedia of Oklahoma History and Culture. Volume 1. Oklahoma City (OK): Oklahoma Historical Society.

Ewan, J. 1950. Rocky Mountain Naturalists. Denver (CO): University of Denver Press.

Ewan, J. (editor) 1969. A Short History of Botany in the United States. New York: Hafner.

Featherly, H.I. 1928. Grasses of Oklahoma. Proceedings of the Oklahoma Academy of Science 8:34-37.

Featherly, H.I. 1930. Some grasses not previously reported from Oklahoma. Proceedings of the Oklahoma Academy of Science 10:20.

Featherly, H.I. 1938. Grasses of Oklahoma. Oklahoma Agricultural Experiment Station Technical Bulletin No. 3, Stillwater (OK).

Featherly, H.I. 194-. Oklahoma state tree and floral emblem. Prepared for students of Oklahoma Schools. Stillwater (OK): Department of Botany, School of Arts and Sciences, Oklahoma Agricultural and Mechanical College.

Featherly, H.I. 1943. The cavalcade of botanists in Oklahoma. Proceedings of the Oklahoma Academy of Science 23:9-13. 
Featherly, H.I. 1946. Manual of the Grasses of Oklahoma. Bulletin of the Oklahoma Agricultural and Mechanical College Vol. 43, No. 21, Stillwater (OK).

Featherly, H.I. and C.S. Russell. 1939. The Ferns of Oklahoma (Revised). Oklahoma Agricultural Experiment Station Circular No. 80, Stillwater (OK).

Fernald, M.L. 1938. A flora of Oklahoma. Rhodora 40:179-183.

Fessler, W.J. 1929. Captain Nathan Boone's Journal. Chronicles of Oklahoma 7:58-105.

Folley, P. 2011. The Guide to Oklahoma Wildflowers. Iowa City (IA): University of Iowa Press.

Foreman, C.T. 1941. Nathan Boone trapper, manufacturer, surveyor, militiaman, legislator, ranger and dragoon. Chronicles of Oklahoma 19:322-347.

Foreman, C.T. 1942. Robert Bebb. Chronicles of Oklahoma 21:52-59.

Geiser, S.W. 1956. Thomas Nuttall's botanical collecting trip to the Red River, 1819. Field and Laboratory 24:43-60.

Goodman, G.J. 1958. Spring Flora of Central Oklahoma. Norman (OK): University of Oklahoma Duplicating Services.

Goodman, G.J. and C.A. Lawson. 1978. The botanical itineraries of A.H. Van Vleet. Chronicles of Oklahoma 56:322-330.

Goodman, G.J. and C.A. Lawson. 1995. Retracing Major Stephen H, Long's 1820 Expedition. Norman (OK): University of Oklahoma Press.

Goodman, G.J., C.A. Lawson, and J.R. Massey. 1978. The Oklahoma botanical travels of G.W. Stevens. Proceedings of the Oklahoma Academy of Science 58:144-150.

Graustein, J.E. 1967. Thomas Nuttall Naturalist: Explorations in America 1808-1841. Cambridge (MA): Harvard University Press.

Henson, W. E. 1941. Early Botanists of Oklahoma [Master's thesis]. Stillwater (OK): Oklahoma Agricultural and Mechanical College.

Hoagland, B. 2000. The vegetation of Oklahoma: A classification for landscape mapping and conservation planning. Southwestern Naturalist 45:385-420.

Hodge, F.W. 1907. The narrative of the expedition of Coronado, by Pedro de Castañeda. pp. 273-387. In: J.F. Jameson (editor). Original Narratives of Early American History. Spanish Explorers in the Southern United States 1528-1543. New York: Charles Scribner's Sons.

Holzinger, J.M. 1892. List of plants collected by C.S. Sheldon and M.A. Carleton in Indian Territory in 1891. Contributions from the U.S. National Herbarium 1:189-219.

Hopkins, M. 1943a. Note from the Bebb Herbarium of the University of Oklahoma. Rhodora 45:267-277.

Hopkins, M. 1943b. New Plants for the Oklahoma Flora. Proceedings of the Oklahoma Academy of Science 23:29-30.

Irving, W. 1835. A Tour on the Prairies. Philadelphia (PA): Carey, Lea \& Blanchard.

Jackson, D. 1966. The Journals of Zebulon Montgomery Pike with Letters and Related Documents. Two volumes. Norman (OK): University of Oklahoma Press.

James, E. 1823. Account of an Expedition from Pittsburg to the Rocky Mountains Performed in the Years 1819, 1820 by Order of the Hon. J.C. Calhoun, Secretary of War, under the Command of Maj. S.H. Long, of the U.S. Top. Engineers, Compiled from the Notes of Major Long, Mr. T. Say, and other Gentlemen of the Party. London: Longman, Hurst, Rees, Orme, and Brown. Three volumes.

Jeffs, R.E. 1931. A Key to the Ferns and Seed Plants of Oklahoma. Norman (OK): University Mimeograph Publishers.

Jeffs, R.E. and E.L. Little, Jr. 1930. A preliminary list of the ferns and seed plants of Oklahoma. Publications of the University of Oklahoma Biological Survey 2:39_ 101.

Jepson, W.L. 1928. The botanical explorers of California-IV. Madroño 1:188-190.

Johnson, F.L. and T.H. Milby. 1989. Oklahoma Botanical Literature. Norman $(\mathrm{OK})$ : University of Oklahoma Press.

(C) Ronald J. Tyrl and Paula A. Shryock Journal compilation (C) 2013 Oklahoma Native Plant Society 
Johnson, F.L. and B.W. Hoagland. 1999. Catalog of the Woody Plants of Oklahoma: Descriptions and Range Maps. http://www.biosurvey.ou.edu/shrub/shr ubndx.htm.

Kelting, R.W. and W.T. Penfound. 1953. Literature on the vegetation of Oklahoma. Proceedings of the Oklaboma Academy of Science 34:126-135.

Latrobe, C.J. 1835. The Rambler in North America; MDCCCXXXIIMDCCCXXXIII. Two volumes. London: R.B. Seeley and W. Burnside.

Lawrence, G.H.M. 1951. Taxonomy of $V$ ascular Plants. New York: Macmillan.

Lawson, R.M. 2004. The Land Between the Rivers, Thomas Nuttall's Ascent of the Arkansas, 1819. Ann Arbor (MI): University of Michigan Press.

Little, E.L. Jr. 2000. Forest Trees of Oklahoma How to Know Them. Oklahoma Forestry Services, State Department of Agriculture Publication No. 1, Revised Edition No. 16, Oklahoma City (OK).

Little, E.L. 1980a. The Audubon Society Field Guide to North American Trees Eastern Region. New York: Alfred A. Knopf.

Little, E.L. 1980b. The Audubon Society Field Guide to North American Trees Western Region. Alfred A. Knopf, New York. Lottinville, S. 1980. Editor's introduction. pp. ix-xxiv. In: T. Nuttall. A Journal of Travels into the Arkansas Territory During the Year 1819. Norman (OK): University of Oklahoma Press.

Magrath, L.K. 1971. Native orchids of Kansas. Transactions of the Kansas Academy of Science 74:287-309.

Magrath, L.K. 2001. Native orchids of Oklahoma. Oklahoma Native Plant Record 1:39-66.

McCoy, D. 1968. A Study of Flowering Plants. Abilene (TX): Hardin-Simmons University.

McCoy, D. 1976. Roadside Flowers of Oklahoma. Lawton (OK): C \& J Printing Company.
McCoy, D. 1978. Roadside Flowers of Oklahoma. Volume II. Lawton (OK): C \& J Printing Company.

McCoy, D. 1980. Roadside Wild Fruits of Oklahoma. Norman (OK): University of Oklahoma Press.

McCoy, D. 1981. Roadside Trees and Shrubs of Oklahoma. Norman (OK): University of Oklahoma Press.

McCoy, D. 1987. Oklahoma Wildflowers. Oklahoma City (OK): Self-published.

McDermott, J.F. 1944. The Western Travels of Washington Irving. Norman (OK): University of Oklahoma Press.

Means, F.H.Jr. 1969. V ascular Plants of Southeastern Oklahoma from the San Bois to the Kiamichi Mountains [dissertation]. Stillwater (OK): Oklahoma State University.

Milby, T.H. 1977. Literature on the vegetation of Oklahoma, 1964-1975. Proceedings of the Oklahoma Academy of Science 57:176-184.

Milby, T.H. and W.T. Penfound. 1965. Additions to the literature on the vegetation of Oklahoma. Proceedings of the Oklahoma Academy of Science 45:23-33.

Milby, T.H. and D.J. Hough. 1988. Proceedings of the Oklahoma Academy of Science: Index to Volumes 1-65, 1920-1985. Tulsa (OK): Oklahoma Academy of Science.

Milby, T.H., F.L. Johnson, and B. Burke. 2008. Oklahoma Landscapes: A Century of Change. Oklahoma City (OK): Oklahoma Heritage Association.

Neal, J.C. 1895. Oklahoma Weeds. Oklahoma Agriculture Experiment Station Bulletin No. 17. Stillwater (OK).

Nuttall, T. 1821. Journal of Travels into the Arkansa Territory during the Year 1819 with Occasional Observations on the Manners of the Aborigines. Philadelphia (PA): Thomas. W. Parker.

Nuttall, T. 1837. Collections towards a flora of the territory of Arkansas. Transactions of the American Philosophical Society 5:139-203.

Ortenburger, A.I. 1928a. Plant collections representative of some typical communities in western Oklahoma. 
Proceeding of the Oklahoma Academy of Science 8:49-52.

Ortenburger, A.I. 1928b. Plant collections representative of some typical communities in eastern Oklahoma. Proceeding of the Oklahoma Academy of Science 8:53-57.

Pammel, L.H. 1911. Manual of Poisonous Plants, Chiefly of Eastern North America. Cedar Rapids (IA): Torch Press.

Pammel, L.H. 1923. A day near Muskogee Oklahoma. Proceedings of the Iowa Academy of Science 30:295-296.

Pike, Z.M. 1810. An Account of Expeditions to the Sources of the Mississippi, and through the Western Parts of Lonisiana, to the Sources of the Arkansaw, Kans, La Platte, and Pierre Jaun, Rivers; Performed by Order of the Government of the United States during the years 1805, 1806, and 1807. And a Tour Through the Interior Parts of New Spain, When Conducted Through these Provinces, by Order of the Captain-General, in the Year 1807. Philadelphia (PA): C. \& A. Conrad \& Co.

Prier, C.W. 1923a. A Systematic and Ecological Study of the Gramineae, Cyperaceae and Juncaceae of the Vicinity of Norman, Oklahoma [Master's thesis]. Norman (OK): University of Oklahoma.

Prier, C.W. 1923b. Fall grasses of Cleveland County, Oklahoma. Proceedings of the Oklahoma Academy of Science 3:83-87.

Reveal, J.L. 1998. History of Systematic Botany: Thomas Nuttall. PBIO 250 Lecture Notes. (http://www.life.umd.edu? emeritus/revea 1/pbio/pb250/pltax62.html accessed 20 October 2006).

Rice, E.L. and G.L. Cross. 1990. A History of the Department of Botany and Microbiology at the University of Oklahoma: The First Hundred years. Norman (OK): University of Oklahoma Foundation.

Romero-González, G.A., G.C. FernándezConcha, R.L. Dressler, L.K. Magrath, and G.W. Argus. 2002. Orchidaceae. pp. 490651. In: Flora of North America Editorial Committee (editor) Flora of North America
North of Mexico, Volume 26. New York: Oxford University Press.

Shirk, G.H. 1950. Peace on the plains. Chronicles of Oklahoma 28:2-41.

Sibley, G.C. 1927. Extracts from the diary of Major Sibley. Chronicles of Oklahoma History 5:196-218.

Smith, M. and P.M. McKenzie. 2013. Schoenoplectiella $\times$ magrathii (Cyperaceae), a new interspecific hybrid between $S$. hallii and $S$. saximontana from Oklahoma. Phytoneuron 2013-18:1-10.

Stemen, T.R. and W.S. Myers. 1929. Spring Flora of Oklahoma with Key. Oklahoma City (OK): Harlow Publishing.

Stemen, T.R. and W.S. Myers. 1937. Oklahoma Flora. Oklahoma City (OK): Harlow Publishing.

Stevens, G.W. 1916. The Flora of Oklahoma [dissertation]. Cambridge (MA): Harvard University.

Strother, J.L. and M.A. Wetter. 2006. Grindelia. pp. 424-436. In: Flora of North America Editorial Committee (editor) Flora of North America North of Mexico, Volume 20. New York: Oxford University Press.

Thwaites, R.G. (editor) 1905. Early Western Travels, 1748-1846. Vol. 13 Nuttall's Travels into the Arkansa Territory, 1819. Cleveland $(\mathrm{OH})$ : Arthur H. Clarke Company.

Taylor, C.E.S. 1997. Keys to the Asteraceae of Oklahoma. Durant (OK): Southeastern Oklahoma State University Herbarium.

Taylor, C.E.S. 1999. Keys of genera of Asteraceae. pp. 288-307. In: G.M. Diggs Jr., B.L. Lipscomb, and R.J. O'Kennon. Shinner's \& Mabler's Illustrated Flora of North Central Texas. Fort Worth (TX): Botanical Research Institute of Texas.

Taylor, R.J. and C.E.S. Taylor. 1978. An Annotated List of Rare or Infrequently Collected Vascular Plants that Grow in Oklahoma. Publication No. 2. Durant (OK): Southeastern Oklahoma State University.

Taylor, C.E.S. and R.J. Taylor. 1983. New species, new combination and notes on 
the goldenrods (Euthamia and SolidagoAsteraceae). Sida 10:176-183.

Taylor, R.J. and C.E.S. Taylor. 1994. An Annotated List of the Ferns, Fern Allies, Gymnosperms and Flowering Plants of Oklahoma. 3rd Edition. Durant (OK): Biology Department Herbarium, Southeastern Oklahoma State University.

Thoburn, J.B. and G.C. Wells. 1955. Editors' introduction, pp. x-xii. In: W. Irving. $A$ Tour on the Prairies. Oklahoma City (OK): Harlow Publishing.

Tomer, J.S. and M.J. Brodhead (editors). 1992. A Naturalist in Indian Territory: The Journals of S.W. Woodhouse, 1849-50. Norman (OK): University of Oklahoma Press.

Torrey, J. 1824a. Descriptions of some new grasses collected by Dr. E. James, in the expedition of Major Long to the Rocky Mountains, in 1819-1820. Annals of the Lyceum of Natural History of New York 1:148-156.

Torrey, J. 1824b. Descriptions of some new or rare plants from the Rocky Mountains, collected in July 1829, by Dr. Edwin James. Annals of the Lyceum of Natural History of New York 1:30-36.

Torrey, J. 1827. Some account of a collection of plants made during a journey to and from the Rocky Mountains in the summer of 1820 , by Edwin P. James, M.D. Assistant Surgeon U.S. Army. Annals of the Lyceum of Natural History of New York. 2:161-254.

Torrey, J. 1856. Part 4. Descriptions of the General Botanical Collections. pp. 59182. In: U.S. Senate. Reports of explorations and surveys to ascertain the most practicable and economical route for a railroad from the Mississippi River to the Pacific Ocean. Made under the direction of the Secretary of War, in 18534 , according to acts of Congress of March 3, 1853, May 31, 1854, and August 5, 1854. Part V, VI, and appendices of the report of Lieutenant A.W. Whipple, Corps of Topographical Engineers, upon the route near the thirty-fifth parallel. Serial
Set Vol. No. 761, Session Vol. No.13, 33rd Congress, 2nd Session, Senate Executive Document 78, Part 4. Beverly Tucker Printer, Washington (D.C.).

Tyrl, R.J. 2006. OAS Lifetime Achievement Award Paul Buck. Proceedings of the Oklahoma Academy of Science 86:109-110.

Tyrl, R.J., S.C. Barber, P. Buck, J.R. Estes, P. Folley, L.K. Magrath, C.E.S. Taylor, and R.A. Thompson. 1994a. Key to the V ascular Plant Families of Oklahoma. Noble (OK): Flora Oklahoma Inc.

Tyrl, R.J., S.C. Barber, P. Buck, J.R. Estes, P. Folley, L.K. Magrath, C.E.S. Taylor, and R.A. Thompson. 1994b. Identification of Oklahoma Plants. Noble (OK): Flora Oklahoma Inc.

Tyrl, R.J., S.C. Barber, P. Buck, W.J. Elisens, J.R. Estes, P. Folley, L.K. Magrath, C.L. Murray, A.K. Ryburn, B. Smith, C.E.S. Taylor, R.A. Thompson, J.B. Walker, and L.E. Watson. 2010. Key to the V ascular Plant Families of Oklahoma. Noble (OK): Flora Oklahoma Inc.

Tyrl, R.J., T.G. Bidwell, R.E. Masters, and R.D. Elmore. 2008. Field Guide to Oklahoma Plants. Commonly Encountered Prairie, Shrubland, and Forest Species. 2nd Edition. Stillwater (OK): Oklahoma State University.

Tyson, C.N. 2009. Sibley Expeditions. Pp. 1379-1380. In: D. Everett (editor). Encyclopedia of Oklahoma History and Culture. Vol. 2.

USDA, NRCS. 2013. The PLANTS Database (http://plants.usda.gov, 14 July 2013). National Plant Data Team, Greensboro, NC 27401-4901 USA.

U.S. House of Representatives. 1858. Northern and western boundary line of the Creek country. Letter from the Secretary of War, transmitting reports of Captains Sitgreaves and Woodruff of the survey of the Creek Indian boundary line. April 16, 1858. -- Ordered to be printed, together with the accompanying papers and map. Congressional Serial Set Vol. No. 958, Session Vol. No. 12, 35th 
Congress, 1st Session, H. Exec. Doc. 104. Washington (D.C.): Executive Department Publications.

U.S. Senate. 1846. Message from the President of the United States, in compliance with a resolution of the Senate, communicating a report of an expedition led by Lieutenant Abert, on the upper Arkansas and through the country of the Camanche Indians, in the fall of the year 1845. Read, and referred to the Committee on Military Affairs. July 11, 1846. Ordered to be printed, with the maps and sketches of scenery; and that 2,000 copies in addition to the usual number be printed, 100 of which shall be for the use of the Topographical Bureau. Congressional Serial Set Vol. 477, Session Vol. No. 8, 29th Congress, 1st Session, Senate Document 438, Washington (D.C.): Executive Department Publications. U.S. Senate. 1853. Exploration of the Red River of Louisiana, in the year 1852 by Randolph B. Marcy, captain Fifth Infantry U.S. Army; assisted by George B. McClellan, survey captain U.S. Engineers. Congressional Serial Set Vol. No. 666, Session Vol. No. 8, 32nd Congress, 2nd Session, Senate Executive Document 54. Washington (D.C.): Robert Armstrong Public Printer.

U.S. Senate. 1856. Reports of explorations and surveys to ascertain the most practicable and economical route for a railroad from the Mississippi River to the Pacific Ocean. Made under the direction of the Secretary of War, in 1853-4, according to acts of Congress of March 3, 1853, May 31, 1854, and August 5, 1854. Part V, VI, and appendices of the report of Lieutenant A.W. Whipple, Corps of Topographical Engineers, upon the route near the thirty-fifth parallel. Serial Set Vol. No. 761, Session Vol. No. 13, 33rd Congress, 2nd Session, Senate Executive Document 78, Part 4. Washington (D.C.): Beverly Tucker Printer.
Van Vleet, A.H. 1901. A List of the Ferns and Flowering Plants of Oklahoma. Norman (OK): University of Oklahoma.

Van Vleet, A.H. 1902. Plants of Oklahoma. Territory of Oklahoma, Department of Geology and Natural History, Second Biennial Report, 1901-02. Guthrie (OK): State Capitol Company. [Typewritten copy available from the University of Oklahoma Library).

Waller, A.E. 1942. Dr John Milton Bigelow, 1804-1878: an early Ohio physicianbotanist. Obio History 51:313-331.

Wallis, C.S. 1953. The Spermatophyta of Cherokee County, Oklaboma (Exclusive of the Gramineae, Cyperaceae and Juncaceae) [Master's thesis]. Stillwater (OK): Oklahoma Agricultural and Mechanical College.

Wallis, C.S. 1958. Additions to the Oklahoma flora from the Oklahoma Ozarks.

Proceedings of the Oklahoma Academy of Science 38:3-5.

Wallis, C.S. 1959. V ascular Plants of the Oklahoma Ozarks [dissertation]. Stillwater (OK): Oklahoma State University.

Wardner, D.G. 1939. The Territorial University of Oklahoma [Master's thesis]. Norman (OK): University of Oklahoma.

Waterfall, U.T. 1952. A Catalogue of the Flora of Oklahoma. Stillwater (OK): The Research Foundation, Oklahoma Agricultural \& Mechanical College.

Waterfall, U.T. 1958. A taxonomic study of the genus Physalis in North America North of Mexico. Rhodora 60:107-114, 128-142, 152-173.

Waterfall, U.T. 1969. Keys to the Flora of Oklahoma. 4th Edition. Stillwater (OK): Self-published.

Waterfall, U.T. and C.S. Wallis. 1953. Additions to the Oklahoma flora from Cherokee County. Proceedings of the Oklahoma Academy of Science 34:124-125.

Wheelock, T.B. 1834. Journal of Colonel Dodge's Expedition from Fort Gibson to the Pawnee Pict Village. (23rd Congress, 2nd Session, Senate Document 1, No. 1)

(C) Ronald J. Tyrl and Paula A. Shryock Journal compilation (C) 2013 Oklahoma Native Plant Society 
American State Papers: Military Affairs 5:373382.

Williams, S.T. and B.D. Simison (editors). 1937. Introduction. pp vii-xviii. In: H.L. Ellsworth. Washington Irving on the Prairie or A Narrative of a Tour of the Southwest in the Year 1832. New York: American Book Company.

Winkler, C.H. 1915. The botany of Texas, an account of botanical investigations in Texas and adjoining territory. University of Texas Bulletin 18:1-27.

Wood, A. 1878. From the Indian Territory. Botanical Gazette 3:49-50, 70.

Woodhouse SW. 1852. Report on the Natural History of the Country occupied by the Creek Indians, Made during the Creek Boundary Survey commmanded by Brevet Capt. L. Sitgreaves, U.S. Topographical Engineers, during the year 1849, and by First Lieut. I. C. Woodruff, U.S. Topographical Engineers during the year
1850, by S. W. Woodhouse, M.D., Surgeon and Naturalist to the Expedition. Manuscript, located in National Anthropological Archives, File 3243, Washington, D.C. [Cited in Mater, C.M. and J. S. Tomer. 2006. Mollusks of the 1849-50 Creek boundary Survey. Publications of the Oklahoma Biological Survey 2nd Series 7:1-10.]

Wright, M.H. and G.H. Shirk. 1955. The

Rambler in Oklahoma: Latrobe's Tour with Washington Irving. From Letters in The Rambler in North America by Charles Joseph Latrobe (London, 1835). Oklahoma City $(\mathrm{OK})$ : Harlow Publishing.

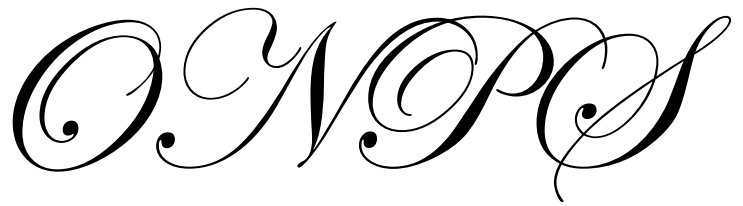

